\title{
On directors' compensation: a multilevel analysis of Spanish listed companies
}

\author{
Fernando Núñez ${ }^{1}$ (D) Ángel Arcos-Vargas ${ }^{1}$. Carlos Usabiaga ${ }^{2}$. \\ Pablo Álvarez-de-Toledo ${ }^{1}$
}

Received: 3 May 2021 / Accepted: 3 December 2021 / Published online: 10 January 2022

(C) The Author(s) 2022

\begin{abstract}
This study analyzes the determinants of the annual compensation of directors belonging to the boards of the Spanish companies that constitute the IBEX 35 stock index. We investigate the importance of observed and unobserved heterogeneity in explaining director compensation. Based on a three-level mixed effect model, our analysis includes time-invariant random effects at company and manager level as determinants of director pay. We find that company effects explain $30 \%$ of the variation in director pay, while company and director effects taken together explain $77 \%$ of that variation. Our findings suggest that the characteristics of the company, in terms of activity sector, size and financial performance, and the professional attributes of the director (especially the role within the board), influence the compensation received. In addition, some directors and companies show random effects (either positive or negative) that significantly separate them from the expected compensation estimated from the fixed part of the model.
\end{abstract}

Keywords Director compensation - Mixed effects model · Firm and director levels . Listed companies

JEL Classification M12 $\cdot$ M21 $\cdot$ D22 $\cdot$ C13

\section{Introduction}

Director remuneration is a recurrent topic of discussion among workers, trade unions and political parties. On the one hand, it is easy to criticize the large amounts of

$\bowtie \quad$ Fernando Núñez

fnunezh@us.es

1 Department of Industrial Organization and Business Management I, University of Seville, Camino de los Descubrimientos s/n, 41092 Seville, Spain

2 Department of Economics, Quantitative Methods and Economic History, Pablo de Olavide University, Seville, Spain 
money these individuals receive compared to average salaries, while on the other hand, it seems fair that the people who have made value creation possible receive a part of it.

Although in the literature there are different opinions about the fair/unfair compensation to the $\mathrm{BoD}$ (board of directors), today nobody doubts their contribution to the growth and development of companies. Therefore, beyond compensation, aspects such as the role and contribution of the BoD are important in themselves. In this field, Nicholson and Newton (2010) analyze the effectiveness of the board from the perspective of directors and senior managers, identifying the impact of board members' profiles and the way in which boards operate on their performance. Meanwhile, Valero and Lucas (2011) state that a board providing professional and highly qualified executives provides confidence to markets, which facilitates access to both credit and new commercial markets.

This study tries to measure the main determinants of directors' compensation in the Spanish economy during the period 2015-2017. The literature on Spain is very scarce in this field—see, for instance, Manzaneque et al. (2011), García Martín and Herrero (2019), Acero and Alcalde (2020) and Melón et al. (2020). The mixed model that we propose in order to estimate the compensation received by an individual member of a BoD as a function of his/her personal attributes and the firm characteristics can be derived from the hedonic theory of wages rooted in the seminal work of Rosen (1974) — see also Eisfeldt and Kuhnen (2013) and Cahuc et al. (2014). Like these authors, we view directors as hedonic goods with multidimensional skill bundles, whose wages are determined analogously to the prices of the hedonic goods. Chiappori et al. (2010) show that hedonic models are canonically equivalent to matching models.

As we could expect, linked to the empirical side of hedonic theory, there are an abundant number of references that include regressions of director compensation on firm and individual characteristics, such as Core et al. (1999), Johnston (2002), Cordeiro and Veliyath (2003), Frydman and Saks (2010), Graham et al. (2012), Sonenshine et al. (2016), Matveyev (2017) and Edmans et al. (2017), among others. Frequently, they are panel, mixed or pooled regressions with data of different time periods, often including fixed or random effects; as we will see later, we focus on mixed models in this study. Usually, director compensation is expressed in logarithms, and so the coefficients of the regressors (for example size, gender dummy, etc.) are interpreted as elasticities or semi-elasticities depending on whether the corresponding explanatory variable is expressed in logarithms or in levels. Frequently, these regressions use lagged variables, for instance measures of past firm performance.

In these references using regression analysis, one or more variables indicate the director category (CEO, Chairman, CFO, internal-external directors, etc.). The most widely used measure for firm size is the market capitalization; however, assets, sales (or revenues) and number of employees are also considered. Regarding size, some regressions also use variables associated with mergers and divestitures. The director's talent is measured using indicators such as career paths, public reputation, educational attainments, and so on. As measures of firm performance, we find the return on assets (ROA), the return on equity (ROE), the stock market return, and the market-to-book ratio, among others. In addition to the level of firm performance, director compensation is also related to its volatility, usually measured by the standard deviation of returns 
over a period of time. Director compensation is also linked to different measures which try to reflect the quality of corporate governance, such as the structure of the board (board size, proportion of external directors, independent or affiliated status, etc.), the ownership structure (percentage of executive and other director's ownership, external blockholders, etc.), the number of directorships the executive holds in other firms, and the use of external peer benchmarking in setting executive compensation. Finally, regressions also consider other director characteristics such as age, tenure, internal or external promotion, gender and board attendance, and other firm characteristics such as industry classification, diversification and R\&D intensity.

In addition to hedonic/regression models, the literature on director compensation has made use of other models which are not in the focus of this paper, but have an important relation to our hedonic approach. Successive developments of assignment models applied to the director labor market have explained the positive assortative matching in the relation between individual talent, firm size and firm performance, to which we referred earlier-see, for instance, Rosen (1981, 1982), Terviö (2008) and Gabaix and Landier (2008). Frydman and Saks (2010) and Gabaix et al. (2014) reassess the validity of this model from a long-term perspective and make an update after the Great Recession, respectively. Two-sided matching models have been employed by Matveyev (2016) to estimate the mutual preferences of firms and directors, and by Pan (2017) to analyze match specificities, driven by complementary elements of firm and director attributes. According to Roth (2015), the process of finding the best professionals responds to a two-sided matching process with asymmetric information, since the applicants (potential directors) have a lot of information on the companies (revenue, employees, debt, sector, ROE, etc., including the remuneration to their current $\mathrm{BoD}$ ), while the companies do not know all the characteristics of the potential directors (training, experience, economic aspirations, personal interests, etc.), creating a problem of unrevealed asymmetric preferences. This asymmetry is the base of the head-hunting firm's business.

The extensive literature on optimal contracting and principal-agent models analyzes the relation between director compensation and firm performance mentioned above. Edmans and Gabaix (2009, 2016) and Edmans et al. (2017) survey this literature, whereas Frydman and Jenter (2010) survey the empirical evidence. In addition, Jensen et al. (2004) review history, analyses and recommendations related to institutional aspects and, finally, Rosen (1992) combines the assignment and contract-agency-incentive issues.

To estimate the determinants of directors' compensation, a three-level model has been applied. This kind of econometric model assumes that the data have a hierarchical structure; the model recognizes the existence of such data hierarchies by allowing for random components at each level in the hierarchy. In our estimation, the fixed portion of the model is based on the characteristics of both the company and the directors currently holding the positions, while the random portion considers the existence of individual effects at the company and director level. Six different models have been proposed, depending on the structure of the random portion. The preferred specification has served to analyze the effect of the different regressors considered on directors' 
compensation and to measure intraclass correlations. Our flexible model lets us combine directors and CEOs in the same analysis, since we control for the category within the board and for unobserved heterogeneity at the company and individual level.

This kind of analysis is relevant for listed companies, since if their directors are being compensated below the model prediction, they could become the target of head-hunting firms, which will make them proposals to change their boards for other more interesting and lucrative ones, thereby depriving the company of their talent and contribution. If, on the contrary, companies are overpaying, they will be reducing their bottom line unnecessarily, thus increasing overheads. The model is also important for top-level directors who are seeking to develop their careers in the field of listed company boards, since it provides them with information on the value of their personal and professional features, as well as on how to complete their experience and qualifications in order to increase their success in the boardroom.

This study, rather than analyzing a specific aspect of directors' market, attempts to offer a consistent econometric estimation of the determinants of directors' compensation in the Spanish economy. The main contributions are three: (1) to contrast the non-validity of the hedonic remuneration model with equally efficient workers through a mixed econometric model; (2) to employ multilevel regression analysis to explain the compensation of a board member in the Spanish economy (a field barely explored so far); and (3) to show that unobserved heterogeneity at the level of companies and individuals must be controlled when explaining director compensation. The fixed coefficients of the mixed model (on observable characteristics of the companies and their directors) are compared with the existing international literature. The model has been applied to the largest Spanish listed companies (IBEX 35), which has been possible thanks to the transparent information on directors' remuneration in Spain in the recent past. This information comes from public and accessible sources, such as companies' annual reports and the annual transparency reports published by the Comisión Nacional del Mercado Valores (CNMV, National Stock Market Commission).

The rest of the paper is structured as follows: After the introduction, Sect. 2 reviews the existing literature on director compensation, Sect. 3 briefly develops the theoretical background of our empirical study, while Sect. 4 describes both the data sample, with variables at individual and company level, and the multilevel methodology. Section 5 applies the multilevel framework to the compensation of the directors of Spanish listed companies. Finally, Sect. 6 highlights the main conclusions.

\section{Related literature}

A director is any person who belongs to the BoD of the company. The mission of the $\mathrm{BoD}$ is to define the long-term strategy of the company, establishing the necessary control mechanisms to ensure that it is accomplished. On the other hand, the Steering or Executive Committee (EC), whose members are called executives, is responsible for resolving the company's operational or tactical issues, which must align the company's operation with the mandates set by the board. Regarding the BoD categories, those directors who are also members of the EC (performing executive functions) are 
called "Executive directors" or, simply, "Executives"; the rest of them are considered non-executive directors. In the literature review we offer below, we will refer first to the vast literature on executive directors' compensation (including CEOs and other executive directors), and then to the literature more specific to non-executive directors' compensation.

The literature on executive directors' compensation has spanned several important topics in economics, such as contract theory, corporate finance, corporate governance, labor economics and income inequality, and is the object of a sizable number of surveys, for example, Rosen (1992), Murphy (1999, 2013), Abowd and Kaplan (1999), Johnston (2002), Core et al. (2003), Jensen et al. (2004), Aggarwal (2008), Bertrand (2009), Edmans and Gabaix (2009, 2016), Frydman and Jenter (2010), Frydman and Saks (2010) and Edmans et al. (2017). These studies cover theoretical issues, empirical evidence, historical and institutional perspectives, and directions for future research. Most of this literature on executive compensation refers to the US case, although there are also a number of studies for other countries. The empirical studies cover a temporal span of approximately the last 80 years.

In the literature that analyzes the effect of personal and firm characteristics on executive compensation, the relation between the individual's talent, the firm's size and the firm's performance occupies a prominent place. For example, Cahuc et al. (2014, p. 184) state that when there is positive assortative matching, the most efficient CEOs are hired by the largest firms, which enables them to benefit from higher wages. They also point out that small differences in talent between highly talented individuals give rise to wide differences in remuneration. As Rosen (1981) points out, this property is characteristic of the remuneration of superstars, whether they are CEOs of large companies, sports figures, journalists or lawyers. The aforementioned relation also appears in Himmelberg and Hubbard (2000), Terviö (2008), Gabaix and Landier (2008), Chen (2017), Jung and Subramanian (2017) and, from a more critical point of view, in Elson and Ferrere (2013). Sonenshine et al. (2016) offer a review on this issue.

According to Frydman and Saks (2010), Gabaix et al. (2014) and Edmans et al. (2017), from the mid-1970s, both executive compensation and firm size grew rapidly before the financial crisis, decreased during the crisis, and rebounded afterward, always at quite similar rates. Previously, since 1936, compensation grew at a slower rate than the firm's size. Under the optimal contracting view, there is a positive correlation between executive compensation and firm size because larger firms attract more talented executives and can pay them more because their productivity is amplified by firm size (Edmans and Gabaix 2016). In addition, Bebchuk and Grinstein (2005) find an asymmetry between increases and decreases in size: While increases in firm sizes are followed by higher executive pay, decreases in firm sizes are not followed by reductions in such pay. Alternatively, under the rent extraction view, larger firms are harder for the board to monitor and offer more opportunities for executives to skim (Bebchuk and Fried 2003).

Falato et al. (2015) have studied, for CEOs, the relation between executive compensation and talent. They construct some measures ("credentials") which reflect publicly observable signals of CEO skills based on the quality of CEOs' educational and professional track records and on their external reputations. These authors find that better credentials are positively correlated with CEO compensation and firm performance. 
For its part, Matveyev (2017), following Bloom and Van Reenen (2007), reports a positive correlation among wages, skills and the quality of management practices. Another discussion arises on the generalist or specific nature of executives' talent, abilities and skills, and its relation with compensation, which points to a pay premium for generalist talents - see, for example, Murphy and Zabojnik (2006), Elson and Ferrere (2013), Cremers and Grinstein (2014), Liu and Guo (2017) and Frydman (2019).

The relation between executive compensation and firm performance has also been subject to debate, being possible to identify two points of view: "pay for performance" and "pay without performance." For instance, Sonenshine et al. (2016, p. 1475) state that the financial crisis appears to have altered the determinants of CEO compensation toward pay for performance versus other factors (such as firm size). Rosen (1992), Hall and Liebman (1998), Core et al. (2003), Bertrand (2009), Frydman and Jenter (2010) and Essen et al. (2012) seem also close to the "pay for performance" standpoint, whereas Bebchuk and Fried (2004, 2005), Djankov et al. (2008), or Bell and Van Reenen (2016) place the emphasis on the "pay without performance" perspective; for example, for Bebchuk and Fried (2005), managerial power has played a key role in shaping executive pay. Related to the control of this managerial power, other papers such as Jensen and Murphy (1990), Jensen et al. (2004), Essen et al. (2012), Sonenshine et al. (2016) and Bell and Van Reenen (2016) stress the importance of strong shareholder governance, and the development of formal and informal institutions protecting investors, to align executives' with shareholders' interests.

Another concept framed within the pay-for-performance topic is the one of "pay for luck" (introduced by Bertrand and Mullainathan, 2001), where luck is defined as observable shocks on performance that are beyond the executive's control-Cremers and Grinstein (2014), Bell and Van Reenen (2016) and Chen (2017), among others, have also employed this concept. As we will show throughout this work, our multilevel methodological scheme allows us to identify these types of shocks which, in our opinion, may even be beyond the company's control.

We turn now to the literature on non-executive directors' compensation. The determinants of non-executive directors' compensation have been the object of a specific literature, along with other related issues such as its design and structure, the role that non-executive directors perform on the board, and the efficiency of the system-see, for example, Brick et al. (2006), Farrell et al. (2008), Ting (2016) and Fedaseyeu et al. (2018). In general, the role that the independent directors play on behalf of the shareholders stands out. For example, Ryan and Wiggins (2004, p. 498) claim that "The general consensus in both the popular press and the academic literature is that an independent board of directors results in more effective corporate governance. Researchers and practitioners suggest that inside board members, large boards, CEOs who also chair the board, and entrenched CEOs result in less independent and less effective boards of directors." For their part, Hahn and Lasfer (2011, p. 590-591) state that "the recognition that accomplishment of the tasks of the board rests on the shoulders of non-executive directors was in conjunction with the recognition that executive directors had conflicts of interest that could jeopardize shareholders and stakeholders, but not necessarily that non-executive directors had similar conflicts." 
In the literature on non-executive directors' compensation appears the concept of excess compensation (Brick et al., 2006; Farrell et al., 2008; Ting, 2016), which is defined as the deviation from the predicted market level of the director compensation for a given firm. This market level is modeled as a function of firm characteristics that the board may consider when determining director compensation-our study offers empirical evidence on this overcompensation.

The determinants of non-executive director compensation are not so different from those of executive directors, and even, in some cases, the references do not distinguish between them. Individual's talent, and firm's size and performance also occupy a prominent place. With regard to talent, for example, Fedaseyeu et al. (2018) analyze in detail whether outside director compensation is tied to skills and experiences that enable them to perform board duties (expertise hypothesis), or whether it is tied to their loyalty to the CEO (friendliness hypothesis). Bugeja et al. (2016) find that non-executive director compensation is associated with the director's reputation, experience and connectedness.

The firm's size appears as a positive determinant of non-executive director compensation in a number of studies-see, for example, Hempel and Fay (1994), Ryan and Wiggins (2004), Brick et al. (2006) and Bugeja et al. (2016). These papers relate size to the need of the company to monitor and the difficulty of the directors' tasks derived from firm complexity. There are some exceptions such as Cordeiro et al. (2000), who find no effect of firm size. Other factors increasing the required director's effort and involvement, such as growth, risk, diversification (multinational diversification in particular) and the number of board meetings, are considered in Meeks and Whittington (1975), Hempel and Fay (1994), Cordeiro et al. (2000), Bugeja et al. (2016) and Ting (2016). It is expected that these factors increasing director's effort and involvement will be positively related to director compensation, but in some empirical studies the relation is unexpectedly negative. For example, Bugeja et al. (2016) find a negative effect of growth and an inconsistent effect of risk.

The relation between non-executive director compensation and firm performance has generated a lot of literature, including other associated aspects. Cordeiro et al. (2000) (for outside directors) and Ryan and Wiggins (2004) find a positive impact of firm performance on director compensation. Hahn and Lasfer (2011) discuss the complexity of this question and the difficulty in measuring the effort, contribution and/or performance of non-executive directors. Nevertheless, they find the literature related to non-executive directors strongly supportive of some sort of remuneration which is a function of performance and effort (to align non-executive directors with their duties and make boards more efficient in undertaking their duties). On the contrary, Hempel and Fay (1994) and Bugeja et al. (2016) argue that organization performance does not appear to be significantly related to non-executive director compensation.

Brick et al. (2006) analyze simultaneously the relations between CEO compensation, outside director compensation and firm performance. First, they find a significant positive relationship between $\mathrm{CEO}$ and director excess compensation. Second, they also find evidence that excess compensation (of directors and CEOs) is associated with firm underperformance. They argue that this evidence is consistent with excessive compensation due to mutual back scratching or cronyism. However, Ting (2016) has a different point of view, stating that firms reward directors and supervisors in 
order to retain their valuable human capital and that there is a robust positive effect of excess compensation on future firm performance. Given that directors and supervisors are rewarded for future success, their excess pay may not be considered all that bad.

Another factor which has received particular attention in the non-executive director compensation literature is the ownership structure (i.e., stockholdings by directors and executives). Cordeiro et al. (2000, p. 273), for outside directors, test empirically the hypothesis that "in firms with a higher degree of inside ownership, both executives and directors have a greater incentive to maximize stock returns and thus do not require as much motivation from compensation plans." Chen and Keefe (2018), for the case of China, find that director compensation is negatively related to ownership concentration and state ownership, and conclude that director compensation practices that differ from western practices are shaped by different ownership structures. These authors also find that director busyness (directors who hold more than two directorships at the same time) positively influence director compensation and related directors (nonindependent directors holding positions in both the listed firms and controlling firms) negatively influence director compensation.

Cordeiro et al. (2000, p. 273) consider the effect of "external monitoring of directors by institutional and other activist investors, and by security analysts. These external monitors scrutinize director and manager decisions more closely and potentially increase the possibility of costly lawsuits against the board. In view of the greater director effort elicited by increased external monitoring, directors might well require higher compensation." He finds some support for this proposition.

There are still some other factors that may affect the compensation of non-executive directors, such as tenure (Ryan and Wiggins 2004; Chen 2017) with a positive influence, gender (Chen 2017, who does not find any effect) or liquidity (Bugeja et al. 2016, who find a positive effect). Finally, and from a more general point of view, Hempel and Fay (1994) state that market-driven compensation systems are the dominant form used by large organizations to pay outside directors, with a major goal being the attraction and retention of these directors. For these authors, the best way to identify the appropriate level of compensation for directors would be to survey other corporations.

\section{Theoretical background}

Perfect competition in the labor markets is compatible with wage heterogeneity as long as some jobs are more demanding than others (for example, because they require more skills) and some workers are more willing to accept these kinds of high-demanding jobs than others. Perfect competition assures that these requirement differences are compensated by wage differentials. This is the essence of the hedonic theory of wages, in which there is a market for each kind of job corresponding to a certain batch of labor conditions and required skills.

Following Cahuc et al. (2014), in this section we briefly describe a hedonic model of remunerations which can be applied to the BoD. Let us suppose an economy where there exists a continuum of jobs, each requiring one unit of labor but a different combination of features $v$. This variable $v$ is a synthetic measure of the required skills and the non-wage conditions of the jobs-conditions such as accident risk, hours 
of work and environment. Mathematically, $v$ can be seen as a vector with as many coordinates as characteristics has the job position. For the sake of simplicity, let us divide $v$ into environment characteristics $e$, routine skills $r$ and cognitive skills $c$ and keep the first two $\{e, r\}$ constant. The productivity of each type of job $y$ is an increasing and concave function of the job cognitive skill requirements $c, y=f(c)$, with $f^{\prime}(c)>$ $0, f^{\prime \prime}(c)<0$, and $f(0)=0$. Productivity $(y)$ has a particular definition: It corresponds to the maximum or efficient production associated with each set of attributes $\{e, r$, $c$ \} net of any costs occasioned by employment, except those related to remuneration. For example, if we interpret $c$ as a measure of managerial competences, jobs more demanding of those competences have higher productivity in our model. A worker with information about all job vacancies, and enjoying perfect mobility, is able to search in different markets and choose the vacancy which provides the greatest utility or satisfaction. The optimization problem is as follows (where $\theta$ is the level of aversion to cognitive effort):

$$
\max _{c} U(f(c), c, \theta)=f(c)-c \theta \text { s.t. } w(c)=f(c) \text { (Perfect comp.condition) }
$$

According to the so-called effort aversion phenomenon, some workers can avoid choosing effortful well-paid jobs even when they recognize that they will provide them with a better working experience. This aversion, applied to cognitive tasks, is named $\theta$ in our model-developing cognitive tasks can be unpleasant and/or tiring for some workers. The optimal solution, given by $f^{\prime}(c)=\theta$ (first-order condition), indicates that a job seeker chooses the job, i.e., the value of $c$, in which the marginal return to cognitive effort $f^{\prime}(c)$ is equal to the disutility $\theta$ derived from the aversion to cognitive effort. As $f^{\prime}(c)$ is decreasing with $c$, the optimal choice of $\operatorname{cognitive}$ effort $c^{*}$ increases when effort aversion $\theta$ decreases.

Our model is compatible with the relatively high remuneration received by the directors of the $\mathrm{BoD}$. Given that the equilibrium wage received by a worker of type $\theta$ amounts to $w[c(\theta)]=f[c(\theta)]$, it is true that: $w\left[c\left(\theta_{1}\right)\right]>w\left[c\left(\theta_{2}\right)\right]$ if $\theta_{1}<\theta_{2}$. Every listed company may be thought of as a productive unit requiring one unit of labor (one director) to cover a job position with a particular high-demanding combination of attributes different from remuneration, especially cognitive skills. Only workers with a low aversion to (cognitive) effort will be suitable for these kinds of vacancies.

The usual way to contrast the hedonic theory of wages consists of using microdata to estimate a regression model of the remuneration received by an individual as a function of personal characteristics and the non-remuneration characteristics of the job. In the hedonic model, remuneration differences reflect differences in working conditions $\{e, r, c\}$ with all workers showing the same efficiency, and all jobs having identical productivity $y=f(c)$ if the work performed is identical. Breaking these assumptions about equal efficiency affects the relation $y=f(c)$ as a technological shift parameter and can generate contradictory results within the model, such as that of a negative relationship between effort and remuneration-Cahuc et al. (2014, p. 175). In empirical and econometric terms, the differences in efficiency between individuals (or firms) exist but are hardly observable - although proxy variables can be proposed. For example, in a BoD, individual efficiency depends on factors such as motivation and 
talent, features which are usually unobserved in empirical data. If the motivation of the director is not statistically controlled, and if it influences the relation $y=f(c)$ as a shift parameter, the regression model does not permit us to estimate correctly the impact of working conditions on remuneration, generating biased coefficients. For example, it could happen that a very motivated (efficient) director earned more than another less motivated (all other personal attributes equal), even holding a less demanding position in the board; this positive effect of the motivation variable would be hidden in the error term of the regression model. The need to correct biases in the regression model (linked to the existence of unobserved variables) justifies the use of multilevel models to estimate hedonic remunerations.

\section{Data and methodology}

This section begins with a detailed description of the microdata sample under study (directors of the IBEX 35 companies in the period 2015-2017). The microdata corresponds to the directors of 34 out of the 35 companies that comprise the IBEX 35 stock index; we have 1458 sample observations with information about 531 directors and 34 firms (no complete data was found for the IBEX 35 company ARCELORMITTAL). The data has been obtained from official and public sources: National Securities Market Commission (CNMV), Iberian Balance Analysis System (SABI), corporate websites and Spanish Exchanges and Markets (BME).

The analyzed variables can be divided into two groups: one that corresponds to individual attributes of the directors, and a second one that describes the characteristics of the companies. The endogenous variable in our subsequent multilevel analysis will be the annual compensation of each director, which is composed of several elements: Remuneration $=$ Salary + Fixed rem.+ Allowances + Short-term variable rem.+ Long-term variable rem. + Rem. for belonging to board committees + Compensations + Other concepts. According to available literature, director compensation may depend on personal attributes and firm-level features. In our data, the annual remuneration paid to the $\mathrm{BoD}$ as a whole represents a percentage of firms' annual revenue that ranges between $2.2 \%$ and $0.007 \%$, the mean value being $0.2 \%$.

Table 1 shows a statistical summary of the quantitative variables in the sample. At individual (director) level, the average payment observed in the sample is $€ 473.9$ thousand per year, the standard deviation of this variable being $€ 964.5$ thousand- - the highest remuneration observed is $€ 12,170$ thousand, which corresponds to the CEO and Chairman of INDITEX group. The average age of the directors (in the year 2017) is 64 years, and the average age in the year of admission to the board is 54 years. In general, the percentage of ownership presents very reduced values: Less than $1 \%$ of the directors have a property in their company that exceeds $1 \%$ - an exception is the president of MELIA-HOTEL, who holds 52\% of the company's property. On the other hand, just over $10 \%$ of the directors belong to more than four boards (including the one registered in the sample), boards of directors that do not necessarily have to be from the IBEX 35 group.

Information about companies in Table 1 basically refers to their size and economic performance. In terms of size, it must be taken into account that IBEX 35 contains 
Table 1 Statistical summary of quantitative variables. Directors and firms. 2015-2017

\begin{tabular}{lllll}
\hline Variable & Mean & Std. Dev & Min & Max \\
\hline $\begin{array}{l}\text { Characteristics of the director } \\
\text { Compensation (thousand } € \text { ) }\end{array}$ & 473.9 & 964.5 & 1 & 12,170 \\
Year of birth & 1955 & 8.9 & 1931 & 1980 \\
Year of entry on the board & 2009 & 6.6 & 1976 & 2017 \\
Year of entry into the firm & 2006 & 10.1 & 1956 & 2017 \\
Ownership (\%) & 0.21 & 2.85 & 0 & 52 \\
Attendances to board meetings per year & $100 \%$ & $10 \%$ & $20 \%$ & $100 \%$ \\
$\quad$ \%) & & & & \\
Belonging to other boards of directors & 2.1 & 1.1 & 1 & 6 \\
Characteristics of the company & & & & \\
Annual revenues (thousand $€$ ) & $14,922,289$ & $15,631,603$ & 216,781 & $54,916,000$ \\
Level of capitalization (thousand $€$ ) & $17,520,761$ & $20,477,438$ & $1,422,865$ & $101,073,024$ \\
Number of employees & 46,173 & 56,300 & 120 & 202,251 \\
ROI (\%) & 4.59 & 7.17 & -18.89 & 31.16 \\
5-year average ROI (\%) & 4.33 & 6.44 & -5.06 & 29.08 \\
ROE (\%) & 14.53 & 25.5 & -123.56 & 123.1 \\
5-year average ROE (\%) & 11.94 & 22.48 & -76.68 & 77.78 \\
Debt ratio (\%) & 98.62 & 118.86 & 0 & 559.2 \\
Export sales (\%) & 54.43 & 33.85 & 0.1 & 99.9 \\
\hline & & & & \\
\hline
\end{tabular}

companies with high, medium and low free-float market capitalization. The companies with the greatest weight (in terms of capitalization) are INDITEX (textile sector), SANTANDER (financial sector), BBVA (financial sector) and TELEFÓNICA (communications), with a capitalization in the year 2017 of $€ 90.5, € 88.4, € 47.2$ and $€ 42.1$ billion, respectively. The smallest companies in 2017 are MELIA-HOTEL ( $€$ 2.6 billion; hotels), INDRA ( $€ 2$ billion; technology and consulting) and TÉCNICAS UNIDAS ( $€ 1.47$ billion; energy infrastructures).

In terms of financial performance, the rates ROI and ROE, for each firm and year (from 2015 to 2017), take the mean values of $4.6 \%$ and $14.5 \%$, respectively, although the standard deviations of these financial rates are relatively high. The correlation between ROE and ROI rates is high (0.71), with INDITEX being the company that shows the highest ROI values (which are greater than $25 \%$ in the years analyzed), and DIA-2015 (retail trade) and AMADEUS-2015 (IT solutions for the travel industry) being the companies that show the highest ROE (123.1\% and 91.8\%, respectively); note that both companies have a high debt ratio. Furthermore, we observe that the correlation between ROI and ROE indicators and the company size (capitalization) is positive although relatively weak: 0.18 and 0.1 , respectively. Looking at the 5-year average rates for the sample period (2015-2017), very different behaviors are observed. Thus, companies such as AMADEUS and INDITEX have obtained, in the analyzed period, 5-year average ROE values larger than $60 \%$, and 5-year average ROI values 
greater than $17 \%$ and $27 \%$, respectively; meanwhile, other companies have obtained negative 5-year average ROE and ROI, as is the case of INMCOLONIAL (real estate), SGAMESA (wind power) or INDRA (technology and consulting), among others.

Table 2 summarizes those qualitative variables in the sample. In terms of gender, it is observed that women represent $19 \%$ of the sample and have a remuneration that does not reach half of that received by men. The lower representation of women on the BoD does not seem to be justified by their academic background. This could be related, in our opinion, to the recent incorporation of women into management positions, as well as their limited presence, some decades ago, in the degree and master programs that most frequently feed the boards of directors today.

As for the variables "Category" and "Position" on the board, we start by clarifying the taxonomy of both terms. As we saw in Sect. 2, those directors who are also members of the EC (performing executive functions) are called "Executive directors" or, simply, "Executives." The remaining members of the BoD (non-executive directors) can be classified into three groups: those who represent the ownership of the firm, called "Dominicals," a name that comes from the Latin word domine, which means owner; those independent professionals of recognized prestige who watch over the good governance of the company, named "Independents"- they protect small and unrepresented shareholders; and those cases difficult to classify in the previous categories according to the information available on the director, called "Ordinary directors."

Regarding the BoD positions, there is at least one person in the company who is simultaneously a member of the $\mathrm{BoD}$ and the $\mathrm{EC}$, reporting to the $\mathrm{BoD}$ about the performance of the company, and transmitting BoD's mandates to the EC. This relevant and demanding role is assumed by the Chief Executive Officer (CEO), the person in charge of ensuring the transmission of the company strategy to day-to-day operations. The "Chairman" of the company has the responsibility of leading the BoD. In some cases, this individual may be simultaneously a member of the EC, in which case he/she is called "Executive Chairman" or "Chairman \& CEO."

According to our data, Independent (52\%) and Dominical $(22.7 \%)$ categories are those that predominate in the sample; for their part, Executive directors represent only $16.3 \%$ of the sample and have an annual average compensation close to $€ 2$ million, far superior to that earned by the rest of the categories - the category Others is grouping the rest of external directors.

Looking at the vertical position within the board, Chairman and CEO directors represent around $12 \%$ of the sample; those directors who combine both positions have an annual average remuneration that exceeds $€ 3.5$ million- the position Ordinary directors includes: Director, 1st, 2nd and 3rd Vice Chair, Vice Chair and CEO, Independent Coordinating Director, and Secretary Counsellor.

Our sample also contains information about the individual's higher education. We can assume that the director's qualification and, to a certain extent, the director's talent are positively related to their level of education. Qualification is defined as "the formal outcome of an assessment and validation process which is obtained when a competent body determines that an individual has achieved learning outcomes to given standards" (European Commission 2018, p. 7), while talent is more related to a person's natural ability to do something well. In our database, the degrees in Economics, Business Administration, and Law represent almost $70 \%$ of the sample, followed by studies in 
Table 2 Director's categorical attributes

\begin{tabular}{|c|c|c|c|}
\hline Accumulated data 2015-2017 & Frequency & Percentage & $\begin{array}{l}\text { Average compensation (thousand } \\
€)\end{array}$ \\
\hline \multicolumn{4}{|l|}{ Gender } \\
\hline Male & 1103 & 80.87 & 532.7 \\
\hline Female & 261 & 19.13 & 223.4 \\
\hline \multicolumn{4}{|l|}{ Category } \\
\hline Independent dir & 709 & 51.98 & 159.5 \\
\hline Dominical dir & 310 & 22.73 & 149.8 \\
\hline Executive dir & 223 & 16.35 & 1978.2 \\
\hline Others & 122 & 8.94 & 373.3 \\
\hline \multicolumn{4}{|l|}{ Position } \\
\hline Ordinary dir & 1198 & 87.83 & 257.9 \\
\hline Chairman & 70 & 5.13 & 1546.7 \\
\hline CEO & 67 & 4.91 & 1857.7 \\
\hline Chairman \& CEO & 29 & 2.13 & 3596.4 \\
\hline \multicolumn{4}{|l|}{ Higher education } \\
\hline $\begin{array}{l}\text { Economics or Business Adm. or } \\
\text { Law }\end{array}$ & 929 & 68.11 & 471.5 \\
\hline $\begin{array}{l}\text { Engineering or Architecture or } \\
\text { Mathematics }\end{array}$ & 274 & 20.09 & 541.8 \\
\hline Others & 95 & 6.96 & 316.8 \\
\hline Without higher education & 35 & 2.57 & 487.6 \\
\hline Engineering and Economics & 31 & 2.27 & 409.3 \\
\hline \multicolumn{4}{|l|}{ Master } \\
\hline Without Master & 874 & 64.08 & 494.2 \\
\hline Business Administration & 275 & 20.16 & 490.2 \\
\hline General Management Program & 120 & 8.8 & 410.4 \\
\hline Economics & 48 & 3.52 & 402.8 \\
\hline Others & 39 & 2.86 & 241.0 \\
\hline Engineering & 8 & 0.59 & 211.4 \\
\hline \multicolumn{4}{|l|}{ Ph.D. } \\
\hline Without Ph.D. & 1161 & 85.12 & 480.8 \\
\hline Economics & 70 & 5.13 & 504.8 \\
\hline Law & 49 & 3.59 & 210.1 \\
\hline Engineering & 40 & 2.93 & 615.2 \\
\hline Others & 26 & 1.91 & 604.2 \\
\hline Business Administration & 18 & 1.32 & 123.1 \\
\hline
\end{tabular}


Engineering, Architecture, and Mathematics (20\%). Only 36\% of the directors have a master degree (mainly in Business Administration), and only $15 \%$ of the sample has Ph.D. studies (which are mainly in Economics).

Figures 1 and 2 relate the average compensation with the firm size and the activity sector, respectively. The firm size is measured in terms of capitalization level, revenues and number of employees (annual average values for the period 2015-2017). In general, it is observed that larger companies tend to offer higher remuneration to their directors, which is a result usually observed in relevant literature (see, for example, Sonenshine et al. 2016, and Liu and Guo 2017) - the $\mathrm{R}^{2}$ coefficients range around $50 \%$ in the three scatters represented in Fig. 1.

The relation between the average compensation by activity sector and the weight of each sector in the IBEX 35 index (measured through the percentage of the total

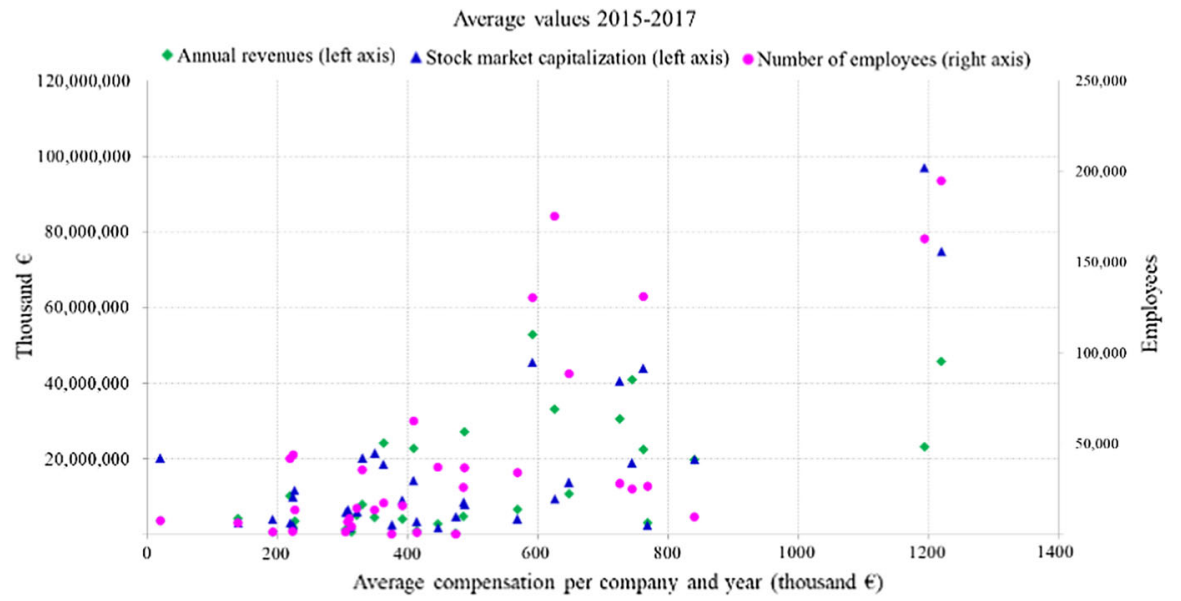

Fig. 1 Relation between company size and average compensation

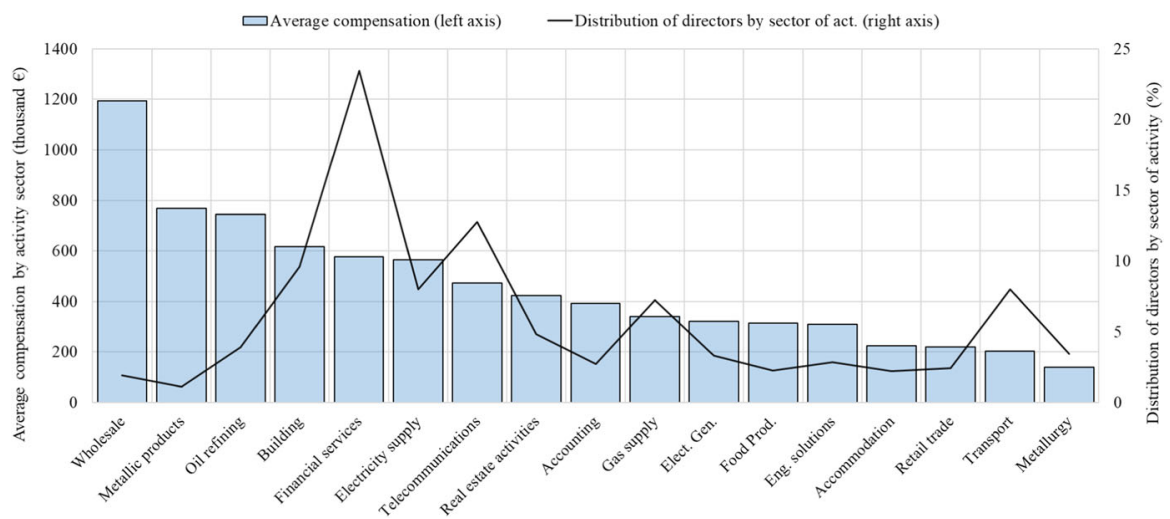

Fig. 2 Relation between the company's activity sector and average compensation 

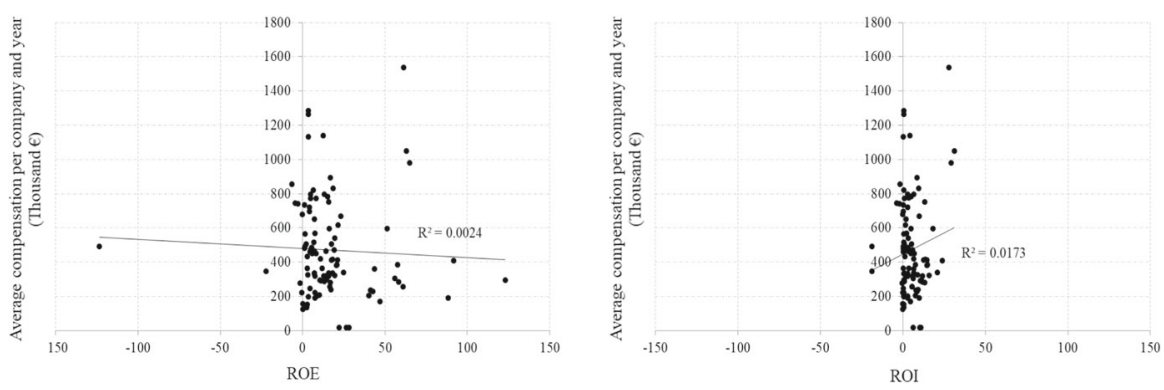

Fig. 3 Relation between performance (ROI and ROE) and annual average compensation by firm

number of directors in the index belonging to each sector) is slightly positive (Fig. 2). Some sectors show relatively high payments, as for example, the wholesale trade $(€$ 1190 thousand), metallic products ( $€ 768$ thousand), oil refining ( $€ 740$ thousand), building ( $€ 610$ thousand), or financial services ( $€ 580$ thousand); the directors of this last sector represent more than $20 \%$ of the IBEX 35 directors.

Our descriptive analysis concludes with Fig. 3, which explores the relation, for each company, between the annual financial performance, measured by the ROE and ROI indicators, and the annual average compensation. Although it is difficult to draw a clear conclusion from the figure, it seems that the relation between director compensation and shareholder profitability (ROE) is slightly negative, while the opposite happens if the performance indicator is the return on investment (ROI); our econometric analysis will shed more light on these relations.

An important feature of our data is that they have a hierarchical structure. Under hierarchical data structures, there is an exact nesting of each lower-level unit in one and only one higher-level unit. Multilevel or hierarchical structures are common in many disciplines (economics, business, medicine, engineering, etc.). Consider, for example, sampling units nested within regions or organizations, or repeated observations over time on individuals. When sampling units form groups or clusters, we might expect that two units from the same cluster will tend to be more similar than two units from different clusters. Hamilton (2013, p. 387) describes mixed-effects models-also known as random effects (RE) models, hierarchical linear models, mixed models or variance components models (Cameron and Trivedi 2005, p. 845) —as a particular regression analysis which allows two kind of effects: fixed effects, meaning intercepts and slopes used to describe the population as a whole, just as in OLS regression; and also random effects, meaning intercepts and slopes that can vary across groups or clusters of the sample.

When there are clusters of sampling units that give the data a hierarchical structure, multilevel models are preferred to OLS models-these later are sometimes called pooled OLS because data on all clusters is combined. OLS regression models assume that sample units are independent; i.e., it is assumed that the estimated residuals are uncorrelated with one another. If data are grouped in one or more levels and we do not control for group effects in our regression model, this independence assumption will not hold. According to Rabe-Hesketh and Skrondal (2012, p. 164), the OLS coefficient 
estimators of the fixed part of the mixed model are unbiased and consistent, but their conventional estimated standard errors are invalid because the residuals are correlated. Goldstein (2011) shows that, as the number of lower-level units in each higher-level unit increases, the OLS estimator increasingly underestimates the true standard errors of the regression coefficients. Hence, confidence intervals based on the OLS estimate will be too short and significance tests will too often reject the null hypothesis of zero slope (this fact may lead us to infer that a predictor has a "real" effect on the outcome when in fact the effect could be ascribed to chance). Correct standard errors will be estimated only if variation among groups is allowed for in the analysis, and multilevel modeling provides an efficient way of doing this. Moreover, Rabe-Hesketh and Skrondal (2012, p. 164) point out another disadvantage of the OLS approach when the residuals are correlated: the estimated coefficients are generally not asymptotically efficient.

The mixed model can be estimated by using maximum likelihood techniques. To derive the likelihood function, we can start from the following linear mixed model:

$$
y=X \beta+Z v+u
$$

where $\mathbf{y}$ is the $n \times 1$ vector of responses, $\mathbf{X}$ is an $n x p$ covariate matrix for the fixed effects $\boldsymbol{\beta}$, and $\mathbf{Z}$ is the $n x q$ covariate matrix for the random effects $\mathbf{v}$. The $n \times 1$ vector of idiosyncratic errors $\mathbf{u}$ is for now assumed to be multivariate normal with mean 0 and variance matrix $\boldsymbol{\sigma}_{\mathbf{u}}^{2} \mathbf{I}_{\mathbf{n}}$. We also assume that $\mathbf{v}$ has variance-covariance matrix $\mathbf{V}$ and that is orthogonal to $\mathbf{u}$ so that:

$$
\operatorname{Var}\left[\begin{array}{l}
\mathbf{v} \\
\mathbf{u}
\end{array}\right]=\left[\begin{array}{cc}
\mathbf{V} & 0 \\
0 & \boldsymbol{\sigma}_{\mathbf{u}}^{2} \mathbf{I}_{\mathbf{n}}
\end{array}\right]
$$

Considering the combined error term $\mathbf{Z v}+\mathbf{u}$, we see that $\mathbf{y}$ is multivariate normal with mean $\mathbf{X} \boldsymbol{\beta}$ and $n x n$ variance-covariance matrix $\boldsymbol{\Omega}=\mathbf{Z} \mathbf{V} \mathbf{Z}^{\prime}+\boldsymbol{\sigma}_{\boldsymbol{\varepsilon}}^{2} \mathbf{I}_{\mathbf{n}}$. Defining $\boldsymbol{\theta}$ as the vector of unique elements of $\mathbf{V}$ results in the log-likelihood:

$$
\mathrm{L}\left(\beta, \theta, \sigma_{\varepsilon}^{2}\right)=-\frac{1}{2}\left\{\mathrm{n} \log (2 \pi)+\log |\boldsymbol{\Omega}|+(\mathbf{y}-\mathbf{X} \boldsymbol{\beta})^{\prime} \boldsymbol{\Omega}^{-1}(\mathbf{y}-\mathbf{X} \boldsymbol{\beta})\right\}
$$

which is maximized as a function of $\boldsymbol{\beta}, \boldsymbol{\theta}, \boldsymbol{\sigma}_{\boldsymbol{\varepsilon}}^{2}$. However, given the high dimension of $\boldsymbol{\Omega}$, the log-likelihood criterion is not usually computed directly on the above expression. Instead, the problem is simplified by subdividing the data into independent clusters (and subclusters if possible) and using matrix decomposition methods on the smaller matrices that result from treating each cluster one at a time. By using orthogonal triangular (QR) decomposition, Pinheiro and Bates (2000) show that maximum likelihood estimates of $\boldsymbol{\beta}, \boldsymbol{\sigma}_{\varepsilon}^{2}$ and $\boldsymbol{\theta}$ are obtained by first maximizing a profiled log-likelihood with respect to $\boldsymbol{\theta}$ - on this procedure, see also StataCorp (2013).

To understand the nested structure of the RE model let us develop the following example, with three levels, applied to a director's compensation: In a three-level scheme, temporary observations of compensations (which constitute the level 1 of the hierarchical structure) are nested in the upper level formed by the directors who earn 
them (which constitutes the level 2)-temporary observations of the compensation of the same director tend to be more alike than observations chosen randomly from the population of directors. At the same time, the directors can be nested in their respective companies or employers (which form the level 3) - directors of the same company tend to be more alike in their labor conditions (including compensations) than directors chosen randomly from the director population. Multilevel models recognize the existence of such nested structures by allowing for idiosyncratic variance components at each level in the hierarchy.

A specific case in which the random effects affect the intercept of a three-level model can be represented as follows ${ }^{1}$ :

Level 1 model : $Y_{t i j}=\beta_{0 i j}+\beta_{1} X_{1 t i j}+\beta_{2} X_{2 t i}+\beta_{3} X_{3 t j}+u_{t i j}$

Level 2 model : $\beta_{0 i j}=\gamma_{00 j}+\gamma_{01} Z_{i j}+v_{0 i j}$

Level 3 model : $\gamma_{00 j}=\alpha_{000}+\alpha_{001} W_{j}+w_{00 j}$

$$
\begin{aligned}
& u_{t i j} \text { iid } \sim \mathrm{N}\left(0, \sigma_{u}^{2}\right), v_{0 i j} \text { iid } \sim \mathrm{N}\left(0, \sigma_{v}^{2}\right), w_{00 j} \text { iid } \sim \mathrm{N}\left(0, \sigma_{w}^{2}\right) \\
& \operatorname{cov}\left(u_{t i j}, v_{0 i j}\right)=0, \operatorname{cov}\left(u_{t i j}, w_{00 j}\right)=0, \operatorname{cov}\left(v_{0 i j}, w_{00 j}\right)=0
\end{aligned}
$$

Integrating the three models, we have:

$$
Y_{t i j}=\alpha_{000}+\alpha_{001} W_{j}+\gamma_{01} Z_{i j}+\beta_{1} X_{1 t i j}+\beta_{2} X_{2 t i}+\beta_{3} X_{3 t j}+\left(v_{0 i j}+w_{00 j}+u_{t i j}\right)
$$

In this three-level model, the subscripts $t, i$ and $j$ denote, respectively, the $t$ th year, the $i$ th director and the $j$ th firm in the sample. The mean prediction of the endogenous variable $Y_{t i j}$-in our case study, $Y_{t i j}$ would be the compensation in year $t$ of director $i$ of company $j$-depends on time-varying variables at different levels $\left(X_{1 t i j}, X_{2 t i}\right.$ and $X_{3 t j}$ ) —examples of these explanatory variables would be, respectively, the position of director $i$ within the board of company $j$ in year $t$, the director's age in year $t$, or the company's revenue in year $t$ - and on the intercept of the group (director) $i j\left(\beta_{0 i j}\right)$; this director-specific intercept, in turn, is composed of the intercept of the group (company) $j\left(\gamma_{00 j}\right)$ plus the part explained by the (continuous or factor) variable $Z_{i j}$ (for example, the gender of the director $i$ of firm $j$ ) plus the net specificity of the director $i j\left(v_{0 i j}\right)$. At the same time, the company $j$ intercept $\left(\gamma_{00 j}\right)$ is composed of the global intercept of the model $\left(\alpha_{000}\right)$ plus the part explained by the (continuous or factor) variable $W_{j}$ (for example, the activity sector of the company) plus the net specificity of the company $j$ $\left(v_{00 j}\right)$.

\section{Results and discussion}

Equation (7) exposes the three-level model that we implement to study the determinants of the annual compensation of directors from the selected listed companies ( $t$ indexes years, $i$ indexes directors and $j$ indexes firms).

\footnotetext{
1 More complex mixed models, for example containing random slopes, can be consulted in Cameron and Trivedi (2005) or Goldstein (2011).
} 


$$
\begin{aligned}
& \log (\text { compensation })_{t i j}=\alpha_{000}+\left(\alpha_{1} \ldots \alpha_{N-1}\right)\left(\begin{array}{l}
D_{\text {SECTOR } 1_{j}} \\
\ldots \\
D_{\text {SECTOR } N-1_{j}}
\end{array}\right)+\gamma_{1} \operatorname{GENDER}_{i j} \\
& +\left(\beta_{1,1} \beta_{1,2}\right)\left(\begin{array}{c}
\text { Year16 } \\
\text { Year1 } 17_{t i j}
\end{array}\right) \\
& +\left(\beta_{2,1} \beta_{2,2}\right)\left(\begin{array}{c}
\mathrm{AGE}_{t i} \\
\operatorname{AGE}_{t i}^{2}
\end{array}\right)+\beta_{3} \operatorname{TALENT}_{t i j}+\beta_{4} \operatorname{INDEMN}_{t i j} \\
& +\left(\beta_{5,1} \beta_{5,2} \beta_{5,3}\right)\left(\begin{array}{c}
D_{\text {EXECUTIVE }_{t i j}} \\
D_{\text {INDEPENDENT }_{t i j}} \\
D_{\text {OTHERS }_{t i j}}
\end{array}\right) \\
& +\left(\beta_{6,1} \beta_{6,2} \beta_{6,3}\right)\left(\begin{array}{l}
D_{\mathrm{CEO}_{t i j}} \\
D_{\text {CHAIRMAN }_{t i j}} \\
D_{\text {CHAIRMAN\&CEO }_{t i j}}
\end{array}\right) \\
& +\beta_{7} \operatorname{ACCRUAL}_{t i j}+\beta_{8} \text { OWNERSHIP }_{t i j} \\
& +\left(\beta_{9,1} \beta_{9,2}\right)\left(\begin{array}{l}
\operatorname{SENIORCOMP}_{t i j} \\
\operatorname{SENIORCOMP}_{t i j}^{2}
\end{array}\right)+\left(\beta_{10,1} \beta_{10,2}\right)\left(\begin{array}{l}
\operatorname{SENIORBOARD}_{t i j} \\
\operatorname{SENIORBOARD}_{t i j}^{2}
\end{array}\right) \\
& +\beta_{11} \text { LOG }\left(\text { REVENUE }_{t j}\right)
\end{aligned}
$$

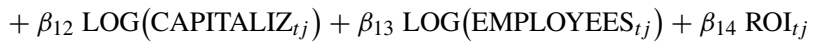

$$
\begin{aligned}
& +\beta_{15} \mathrm{ROE}_{t j}+\beta_{16} \mathrm{DEBT}_{t j} \\
& +\beta_{17} \operatorname{SIZEBOARD}_{t j}+\left(v_{0 i j}+w_{00 j}+u_{t i j}\right)
\end{aligned}
$$

Following the literature on director's compensation, the endogenous variable of our model is the director compensation expressed in logarithms. As for explanatory variables, at the company level, we control for the activity sector; for the company size measured through annual revenues, capitalization, and number of workers; and for the economic performance measured through ROI, ROE and debt ratio. At the worker level, we control for personal attributes such as gender, age and talent; and for professional attributes such as the category and position on the board, the seniority in the company and on the board, the percentage of firm ownership, the annual accrual in the board, and the possible existence of indemnifications. Finally, a temporary dummy variable allows control for the year to which each sample observation corresponds.

All this observed heterogeneity constitutes the fixed part of the mixed model, which allows us to obtain the mean prediction of the dependent variable conditioned on the values of the regressors. The coefficients of the dummy variables (which are activity sector, gender, talent, category and position on the board, indemnification and year) condition the global intercept of the model, while the coefficients of the continuous variables (the rest of regressors) refer to the model slopes or marginal effects.

The mixed model incorporates in this fixed portion a random portion that allows us to control for unobserved heterogeneity through the existence of three levels of residuals: the one due to differences between companies (level 3, $w_{00 j}$ ), the one due to differences between workers (level 2, $v_{0 i j}$ ) once we control for the (observed and unobserved) differences between companies, and the one due to differences between years (level 1, $u_{t i j}$ ) once we control for the (observed and unobserved) differences between companies and between workers. These random effects condition, not the 
mean prediction or expected value of the dependent variable $\left(\right.$ as $E\left(v_{0 i j}\right)=E\left(w_{00 j}\right)=$ $E\left(u_{t i j}\right)=0$ ), but its variance; allowing us to obtain, in addition, individual predictions that take into account that unobserved heterogeneity.

Our three-level model has to be estimated by using maximum likelihood techniques (or by Bayes methods) since it comprises a composite error term whose variance is partitioned into a between-company variance component (the variance of the level 3 residuals), a between-worker variance component (the variance of the level 2 residuals) and a between-year variance component (the variance of the level 1 residuals). Table 3 shows the different specifications that have been estimated, which differ depending on whether the various levels represent fixed or random intercepts and whether some intercept dummy variables are allowed to have random coefficients.

Respective likelihood ratio tests confirm that all multilevel models-models from (2) to (6) —offer a significant improvement over the linear regression model (1). Models (2) and (3) explore the possibility of including random intercepts linked to the activity sector of the company. Model (2) only considers the activity sector as a random intercept, while model (3) also includes another random term linked to the company level. The likelihood ratio $\chi^{2}$ test for the null hypothesis of "no difference in fit between nested models" allows the rejection of that hypothesis for models (2) and (3), favoring the more complex model (3). Moreover, the variance of the random intercept of the activity sector is nonsignificant in model (3), the variance of the random intercept for the company level being significant; therefore, we have chosen to introduce the activity sector in the fixed part of the model (through dummy variables) and the company level as a random intercept, which gives rise to model (4). Model (4) is nested in model (5) which, in turn, is nested in model (6). Model (5) introduces a second source of variation in model (4) by introducing the level of the director (level 2) into the model, while model (6) extends model (5) by allowing some dummy coefficients to be affected by the two nested director and company levels; specifically, random coefficients have been estimated for the factor variables category and position on the board ${ }^{2}$ - the rest of the regressors coefficients do not show random behavior at the two levels considered. The likelihood ratio $\chi^{2}$ test of "no difference in fit between nested models" favors model (5) over model (4) and model (6) over model (5). Moreover, Akaike's and Schwarz's Bayesian information criteria (AIC and BIC) favor model (6), which therefore provides a better representation of the data than the rest of the models.

Table 4 shows the estimated results of models (5) and (6), and also of regression model (1) in order to compare the coefficients obtained. Regarding the fixed part of the model, specifications (5) and (6) offer similar results. Thus, in both models, the payments to directors in years 2016 and 2017 are approximately 7\% higher than those earned in 2015; this percentage moves between 9\% (2017) and 12\% (2016) in the OLS regression (model 1). We must bear in mind that the average annual inflation in the Spanish economy in the three years analyzed has been approximately $1 \%$, and the GDP growth rate was relatively high. This procyclical behavior is also observed in the recent past in the USA - see, for instance, Frydman and Saks (2010), Gabaix et al.

\footnotetext{
2 Note that model (5) is the one that corresponds to Eq. (7), with model (6) incorporating in model (5) purely random effects in the coefficients of dummy variables for Category $\left\{\beta_{5,1}, \beta_{5,2}, \beta_{5,3}\right\}$ and Position $\left\{\beta_{6,1}, \beta_{6,2}, \beta_{6,3}\right\}$ on the board.
} 


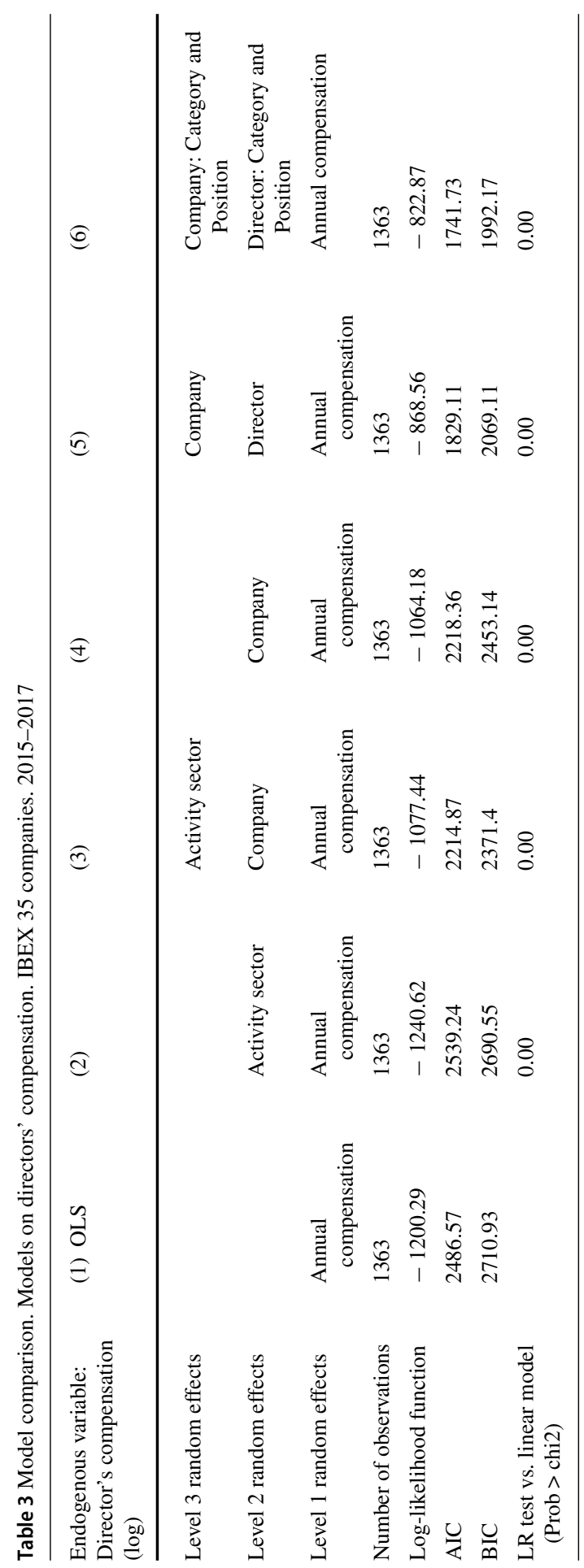




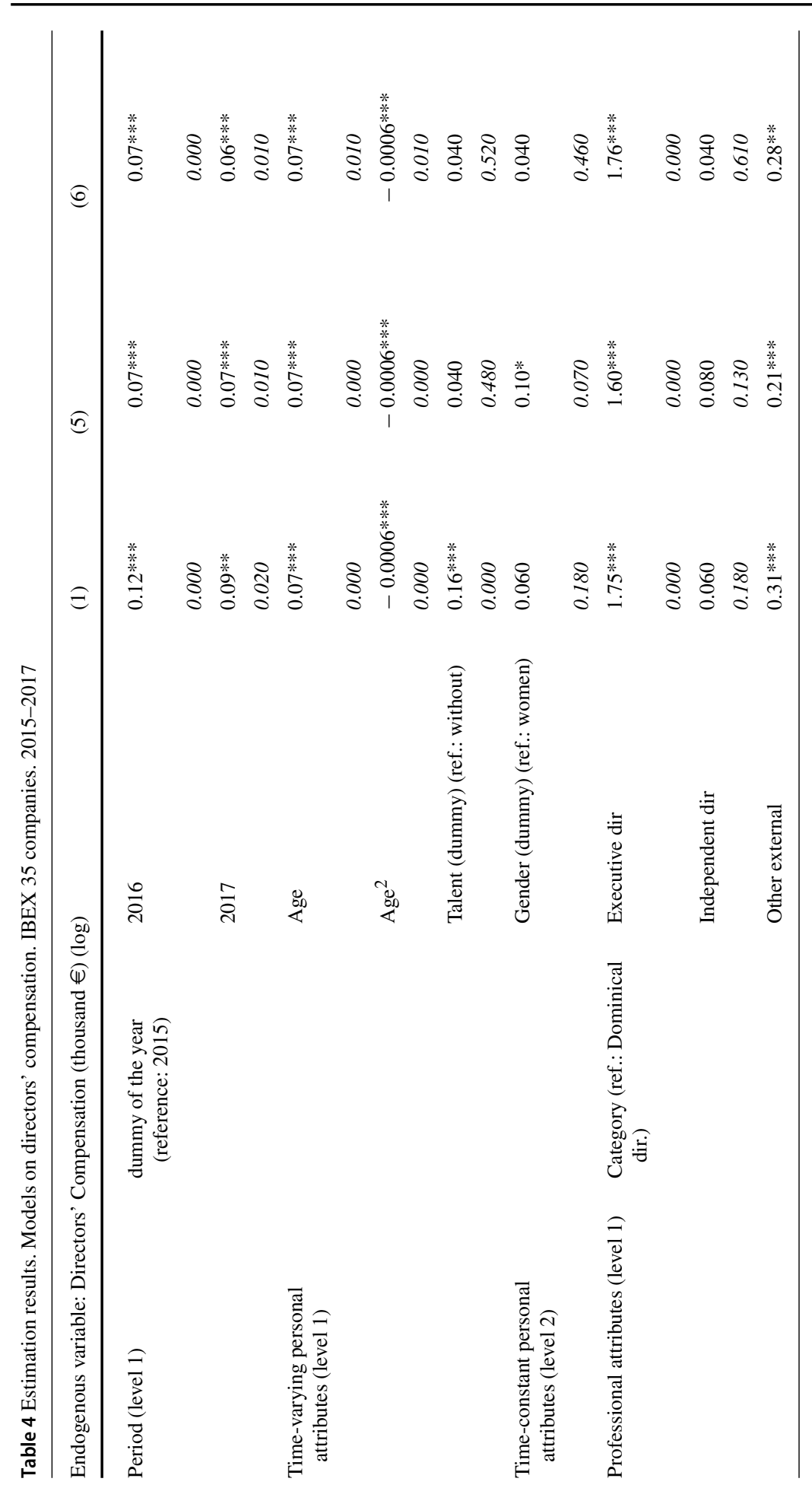




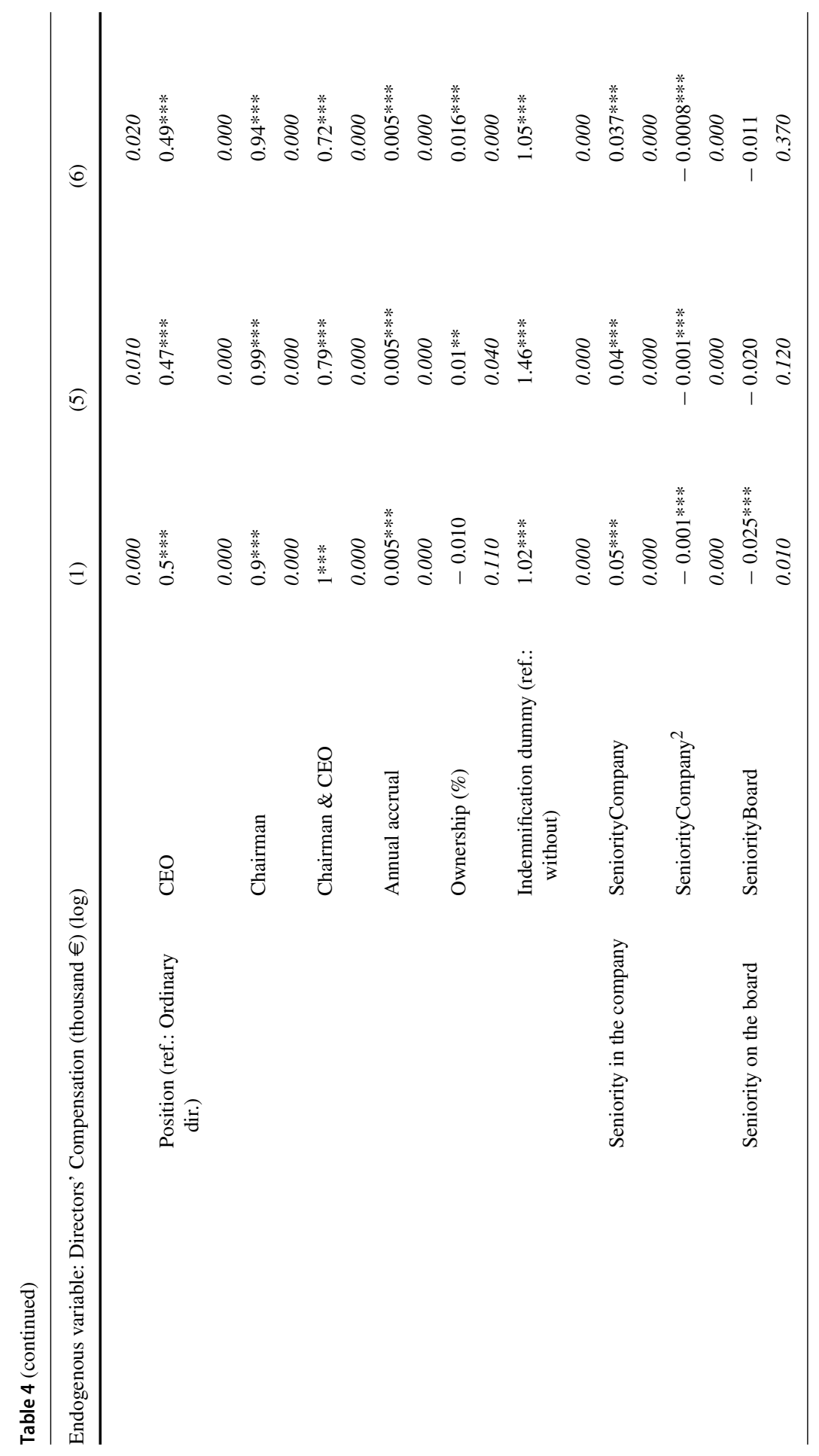




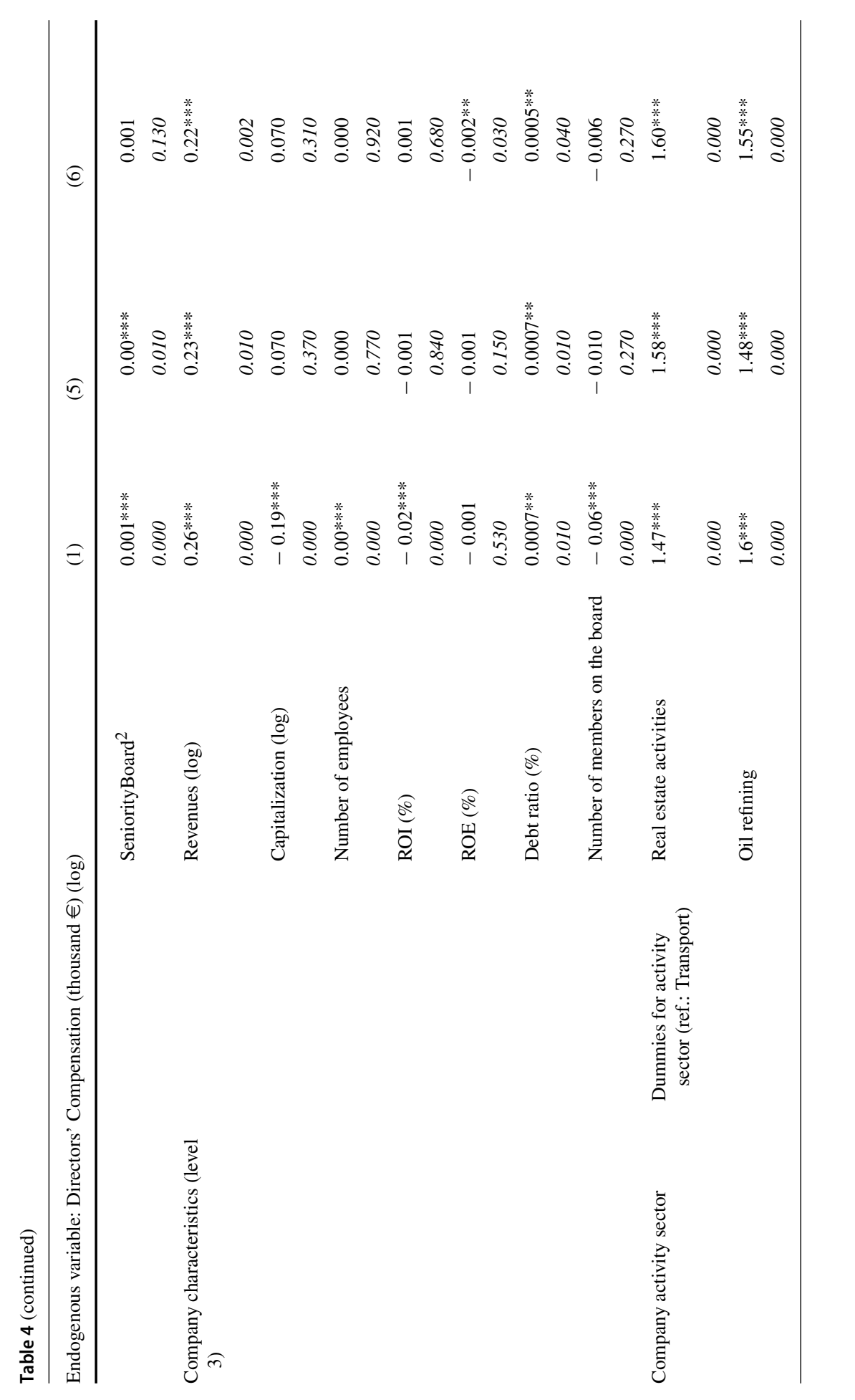




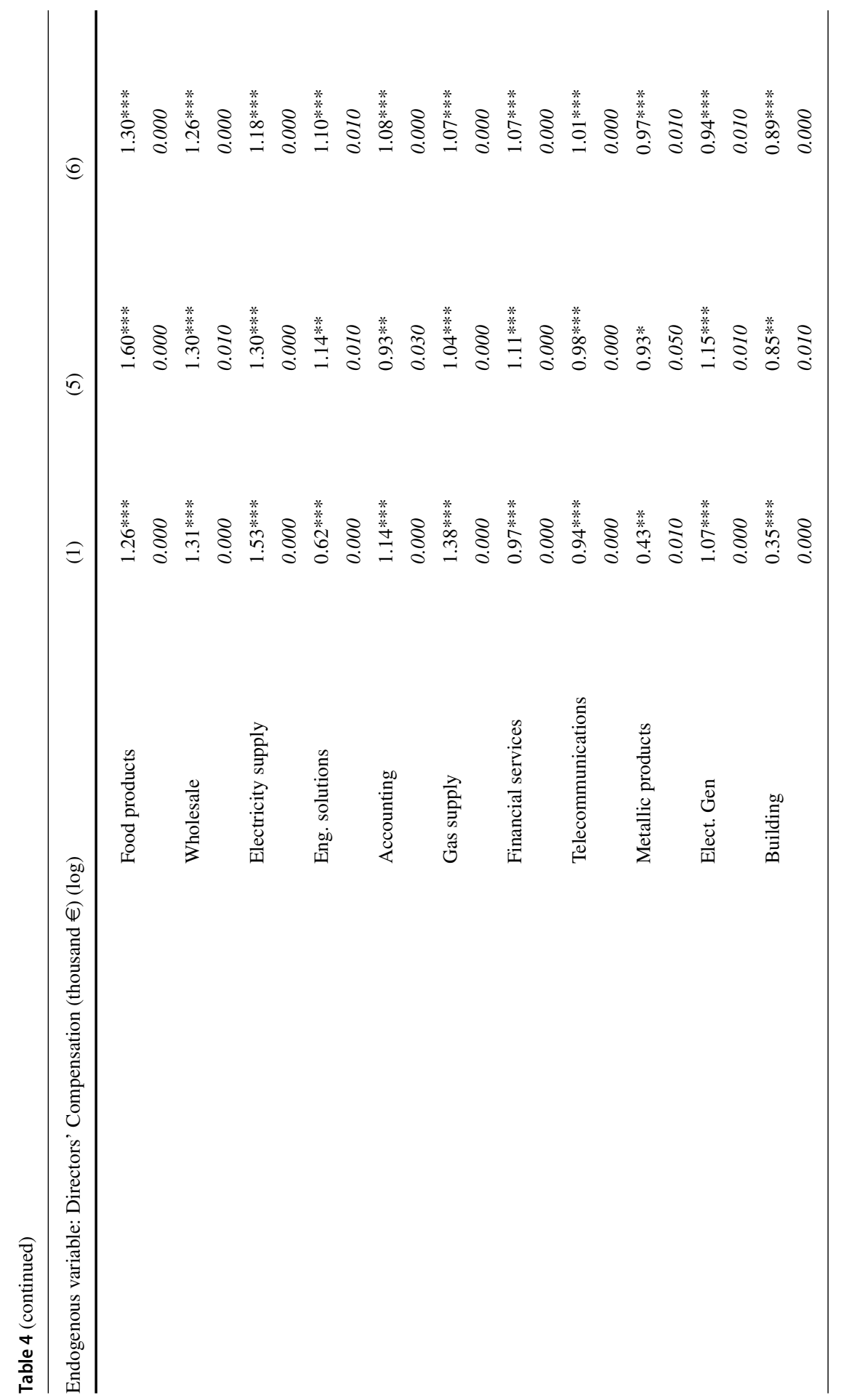




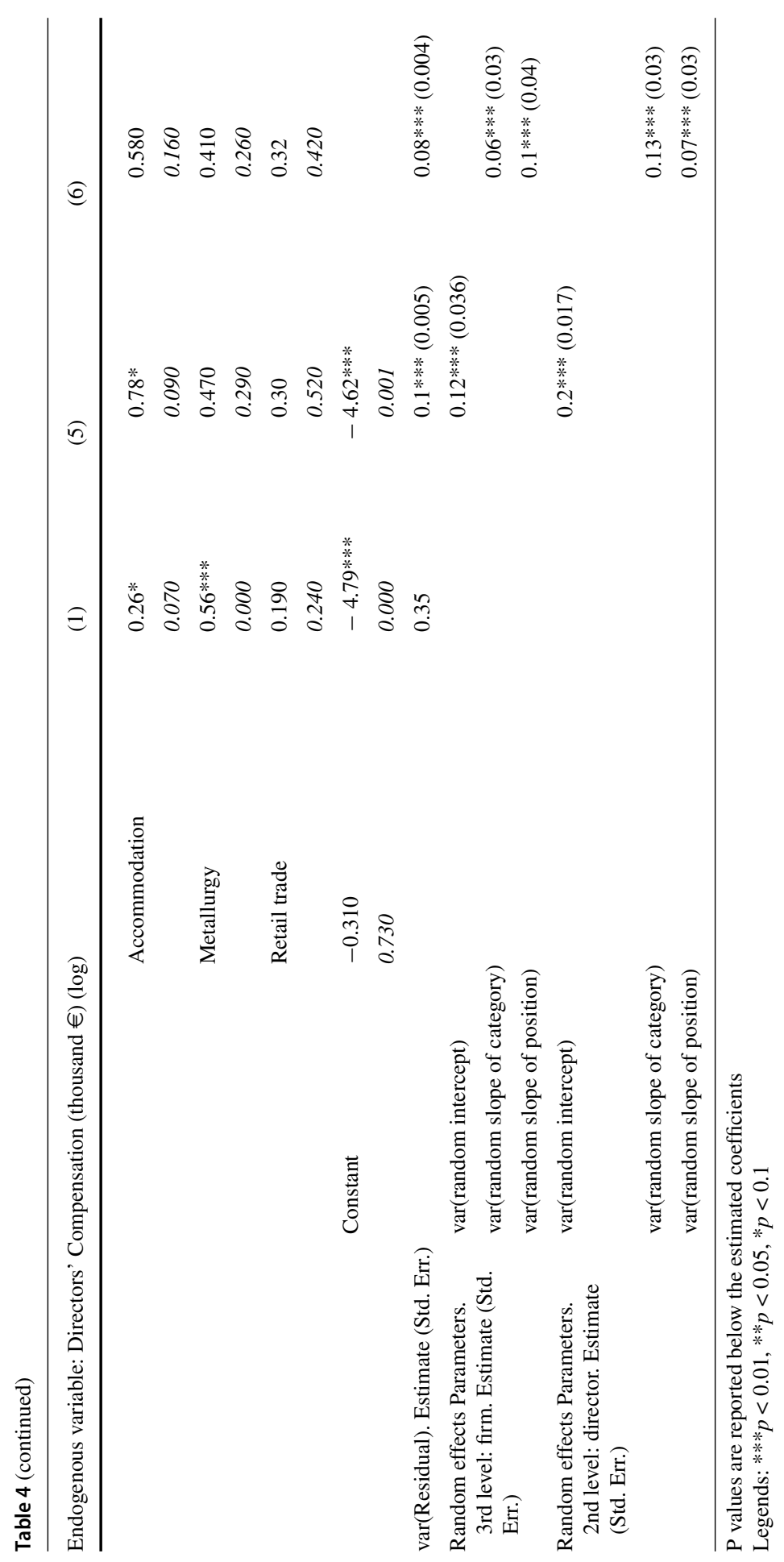


(2014) and Sonenshine et al. (2016); the evidence of this last study also suggests that CEO compensation became more closely linked to firm performance after the 2008 financial crisis.

\section{- Time-varying personal attributes (level 1 variables)}

The effect of a change in the director age on compensation fits (in the three models) to the semi-elasticity $\partial \log$ (payment) $/ \partial$ Age $=0.07-0.0012 \mathrm{Age}$. This derivative determines that the compensation increases with age up to 58 years; from that year on, the relationship turns negative. Johnston (2002) shares our result and states that younger CEOs earning more than their older counterparts may be identifying high-fliers.

To check the hypothesis of Cahuc et al. (2014), according to which the most efficient CEOs are hired by the largest firms, which enable them to benefit from higher compensations, we have built a dummy variable (called "Talent" in the models) that takes value 1 if the director has a master degree and is also in a company located above the median of firms in terms of capitalization (these directors represent $16.2 \%$, $18.5 \%$ and $19.1 \%$ of the sample in the years 2015,2016 and 2017 , respectively). If this interaction effect were significant, it could indicate that, between two individuals with a master degree (i.e., a proxy of efficient or highly talented directors), the one in a larger company receives a higher compensation for talent (once we control for the other characteristics). The coefficient is clearly significant and positive in the OLS model, with payments $17.4 \%(\exp (0.16)-1)$ higher for those talented directors who are in large companies, but this coefficient loses its significance in multilevel models (5) and (6), which would indicate that the compensation premium observed in model (1) is absorbed in those mixed models by the individual and/or company random effects; of course, the unobserved heterogeneity underlying these effects may have to do with the director's talent, requiring further information apart from master studies.

- Time-constant personal attributes (level 2 variables)

The dummy variable for gender is significant in mixed model (5), indicating that men earn $10 \%$ more than women solely for being men; however, this effect is diluted in model (6) when random coefficients are introduced in the factor variables category and position on the board; consequently, the overpayment of males observed in model (5) seems to be related to those factor variables, and not so much to director's gender. This nonsignificant result of gender in model (6) contrasts with the data presented in Table 2 (where one might conclude that female directors have a compensation $60 \%$ lower than that of male directors) and agrees, for example, with the results by Edmans et al. (2017) and Graham et al. (2012); moreover, these last authors point out that observable time-invariant characteristics (such as a gender dummy) can be absorbed into the manager or firm effects.

- Time-varying professional attributes (level 1 variables):

Professional attributes of the directors play an important role in the models. In the most complete specification, model (6), category and position on the board determine both the expected value of the remuneration and its variance. For example, in terms of expected value, those directors who hold the category of Executive director are expected to earn more than five times what a Dominical director earns, 
while those directors who hold the position of Chairman (or Chairman and CEO) are expected to earn more than twice what other directors receive-similar results are offered, for example, by Graham et al. (2012) ${ }^{3}$ and Core et al. (1999); as in our case, the last authors observe that CEO compensation is higher when the CEO is also the board chair.

Other professional attributes showing influence on compensation are the annual accrual (measured in days on the board in each year), with a semi-elasticity of 0.005 ; the ownership percentage, with a semi-elasticity of 0.016 (this result contrasts with those of Core et al. (1999) and Cordeiro and Veliyath (2003); according to this last article, there exists a substitution effect (not observed in our data) between CEO cash compensation and incentives furnished via stock ownership); receiving indemnification, which multiplies the payment by 2.9 ; and seniority in the company (measured in years), which affects compensation following the expression $\partial \log ($ payment $) / \partial$ seniorityinfirm $=0.037-0.0016$ Seniority, which implies that the maximum remuneration is reached after 23 years in the company. Ma and Pan (2017) state that better matched executive-firm pairs last longer and that job tenure can be indicative of human capital investment; both effects can explain the positive relationship between seniority in the firm and director's payment, at least up to a certain level of seniority. Finally, seniority on the board is non-explanatory in the more complete model (6).

\section{- Time-varying company characteristics (level 3 variables)}

Three characteristics of the company, apart from its sector of activity, have been explanatory of the director compensation: sales (or revenues), ROE and debt ratio. The company revenue shows an elasticity somewhat higher than 0.2 - value within the range found in some studies (see, for example, Sonenshine et al. 2016, and Liu and Guo, 2017) ${ }^{4}$ but somewhat greater than the elasticity between 0.06 and 0.11 obtained by Cordeiro and Veliyath (2003) for the US economy. The ROE index coefficient implies a small negative semi-elasticity of -0.002 , which could mean that some kind of trade-off exists between remuneration to shareholders and board; this negative relation is also obtained by Aduda (2011) for the Kenyan banking sector, but contrasts with the positive ROE effect observed for the U.S. by Ma and Pan (2017) and Edmans et al. (2017). Finally, the debt ratio, calculated as $\frac{(\text { Noncurrentliability }+ \text { Financialdebts }) 100}{\text { Equity }}$, shows a very small positive semi-elasticity of 0.0005 .

- Time-constant company characteristics (level 3 variables)

In terms of activity sectors, companies in real estate activities and oil refining pay their directors about five times more than those firms in the transport sector (reference sector in the estimation), while the food products, wholesale, electricity supply

\footnotetext{
3 According to these authors, the dummies for position on the board potentially capture two influences that determine compensation: a person-specific effect (i.e., skillful persons become Chairman or CEO) and a job promotion effect (a pay increase as a result of a non-CEO or Chairman being promoted to CEO and/or Chairman). In models without manager-fixed or random effects, these dummies might be capturing both influences.

4 As Sonenshine et al. (2016), we also tested the market capitalization for firm size (and also the number of employees), but the specification with sales has shown a better fit.
} 
and engineering solutions sectors pay about 3.5 times more than the reference sector, and the accounting, gas supply, financial services, telecommunications, metallic products, electricity generation and building sectors are paying about 2.5-3 times more. Finally, accommodation, metallurgy and retail trade sectors show a pattern similar to that of the reference sector.

The analysis of the random portion of the models begins with the ICC (intraclass correlation coefficient) estimation. Our three-level nested models (5) and (6) present two intraclass correlations. The first is the level 3 intraclass correlation at the company level (the correlation between payments in the same firm), and the second is the level 2 intraclass correlation at the within firm level (the correlation between the payments for the same director and company). Correlations among observations in the same company is 0.3 , while for the same company and director is 0.77 -in other words, $77 \%$ of the overall variation in the response variable is explained simply by clustering the data in three levels. This result contrasts with that obtained by Ma and Pan (2017), which give more relative importance to the firm effect in relation to the director effect - these authors also control for a "match effect" to consider the compensation consequences of increased productivity from positive assortative matching between "good managers" and "good firms."

Mixed-modeling research often focuses on the fixed effects, with random effects included only to control for unobserved heterogeneity in the data. However, random effects can themselves be values of interest. Mixed model estimations offer the possibility of estimating the best linear unbiased predictions (BLUP) of random effects. Figure 4 depicts the random intercepts for companies and workers in the mixed model (5). For example, as can be seen in panel (a), at any level of the explanatory variables in model (5) director's compensation (in logarithms) averaged about 1.4 points lower among AENA directors and about 0.7 points higher among IAG-IBERIA directors. At the same time, panel (b) shows that, controlling for observed heterogeneity and for the random effect of the company, director's compensation (in logarithms) ranges between -2.2 and 1.8 among directors; i.e., some directors earn more (or less) compensation than others for reasons that are not explained by the company effect and the fixed part of the model.

(a) BLUP random intercept for companies

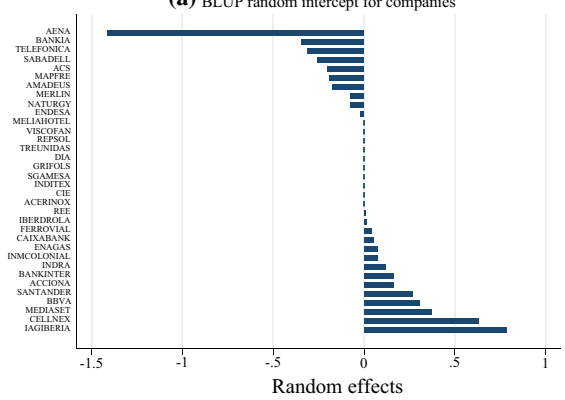

(b) BLUP random intercept for directors

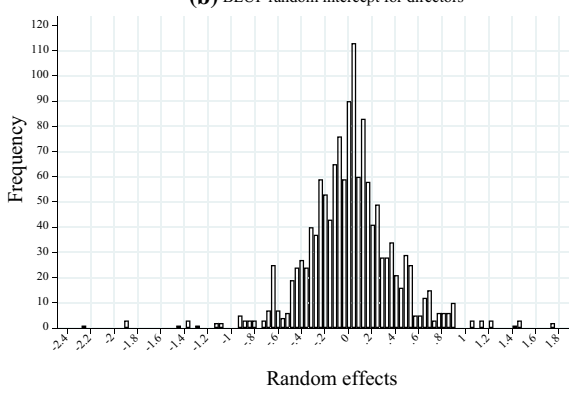

Fig. 4 Level 2 and 3 random intercepts of mixed model (5) 
Table 5 Descriptive analysis of random intercepts in model (6)

\begin{tabular}{|c|c|c|c|c|c|}
\hline \multicolumn{2}{|c|}{ Random intercepts } & Obs. & Std. Dev. & Min. & Max. \\
\hline \multicolumn{6}{|c|}{ (a) Random intercepts by levels and position } \\
\hline \multirow[t]{4}{*}{ Company } & Ordinary directors & 1197 & 0.29 & -1.09 & 0.56 \\
\hline & Chairman and CEO & 29 & 0.26 & -0.66 & 0.35 \\
\hline & Chairman & 70 & 0.20 & -0.32 & 0.50 \\
\hline & CEO & 67 & 0.14 & -0.39 & 0.25 \\
\hline \multirow[t]{4}{*}{ Director } & Ordinary directors & 1197 & 0.13 & -0.86 & 0.60 \\
\hline & Chairman & 70 & 0.13 & -0.32 & 0.29 \\
\hline & Chairman and CEO & 29 & 0.11 & -0.21 & 0.23 \\
\hline & $\mathrm{CEO}$ & 67 & 0.09 & -0.25 & 0.17 \\
\hline \multicolumn{6}{|c|}{ (b) Random intercepts by levels and category } \\
\hline \multirow[t]{4}{*}{ Company } & Dominical & 309 & 0.34 & -1.09 & 0.56 \\
\hline & Independent & 711 & 0.28 & -1.09 & 0.56 \\
\hline & Other external & 120 & 0.23 & -0.43 & 0.43 \\
\hline & Executive & 223 & 0.21 & -1.09 & 0.43 \\
\hline \multirow[t]{4}{*}{ Director } & Executive & 223 & 0.17 & -0.72 & 0.60 \\
\hline & Other external & 120 & 0.15 & -0.31 & 0.48 \\
\hline & Dominical & 309 & 0.12 & -0.55 & 0.60 \\
\hline & Independent & 711 & 0.11 & -0.86 & 0.58 \\
\hline
\end{tabular}

Model (6) supports the hypothesis that random intercepts estimated in model (5) may depend on the position and category of the director within the board ${ }^{5}$-also, other random effects (both intercepts and slopes) have been tested within the model but without significant results. Table 5 shows how the random intercepts at firm level and director level vary across positions and categories on the board. Indeed, there are significant differences between the different labels of those variables. For example, the differences between companies and between directors are accentuated if the position of the director is Ordinary (mainly Vice Chairman) or Chairman - this could be due to the different roles that these kinds of directors can assume in their companies. Additionally, the Executive category shows a larger standard deviation, in relative terms, at the individual level than at the company level; in other words, being an Executive director generates more significant differences (in relation to the other categories) among directors than among companies.

Our empirical analysis concludes by comparing the individual predictions of models (1), (5) and (6) with our real data-see Fig. 5. The points below the bisector imply predicted payments below the observed values, and vice versa; these gaps would be the level 1 residuals in the mixed models. As expected, the model (6) — black dots in the figure-is the one that shows a better adjustment to the bisector, which does not prevent

\footnotetext{
5 The coefficients of variables category and position have been estimated as random slopes in model (6), but given their character of dummy variables ( 0 or 1 ), they end up conditioning the intercept of the mixed model.
} 


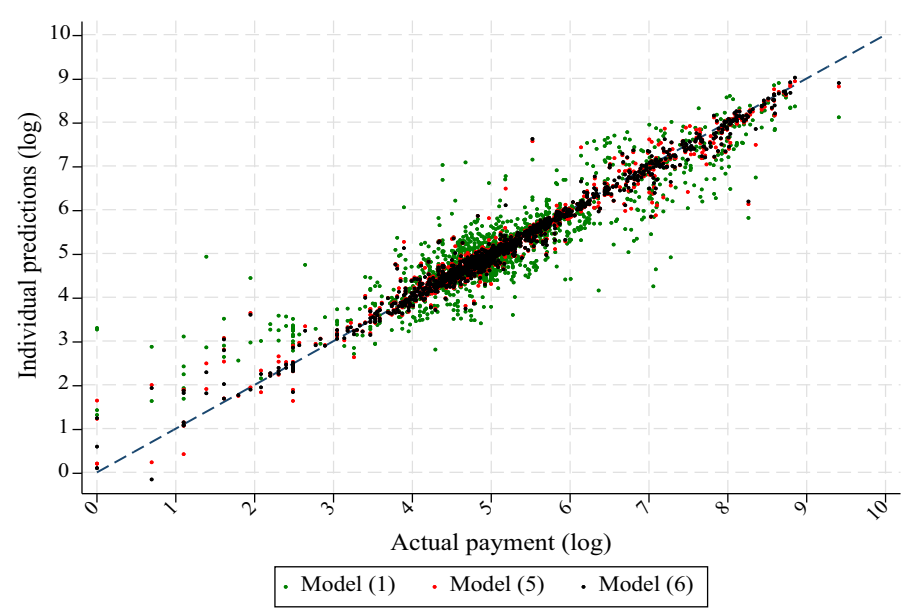

Fig. 5 Individual predictions vs. actual data

it from showing positive and negative level 1 residuals. For example, recovering the levels of the actual and predicted compensation (model (6)), it is observed (and hardly explainable) that some directors are earning 2, 3 and up to 6 times more than the expected value generated by the fixed portion linear prediction plus the contributions based on predicted random effects. Level 2 and 3 residuals of models (5) and (6) may be related to unobserved variables that are relatively stable over time (in the short run), such as the talent, individual's reputation or status, skills and political background of the director, at level 2 (directors), or the degree of internationalization, corporate governance and R\&D expenditure of the company, at level 3 (firms). Moreover, the level 1 residuals are linked to more isolated or infrequent events. In our opinion, the existence of malpractices by some individuals might not be ruled out as explanatory of level 2 and level 1 perturbations-however, we do not think that unfair practices are common at company level, at least in Spain.

\section{Conclusions}

This paper aims to explain directors' compensation of a sample of Spanish listed companies. It is worth noting the scarcity of this type of study in the Spanish market. Our empirical analysis has been possible due to the recently established transparency programs of the national regulators, which provide detailed information on both the companies and directors' curricula vitae. The model proposed is based on a multilevel econometric approach, which uses three random levels (years, directors and firms) to take into account the hierarchical structure of the data. Six specifications have been evaluated with different configurations of the random portion of the model. The results obtained point to significant determinants at both firm and director levels.

The fixed portion of the mixed model begins by showing a $7 \%$ increase in remuneration between 2015 and 2016, but payment stability between 2016 and 2017. This 
payment evolution above overall inflation might be due to the recent focus of companies in Spain on modernizing and professionalizing the governance structures of listed companies, in order to adapt them to codes of best practice. Regarding the company's features, a significant and positive relation is observed for the revenue of the company, presenting an elasticity of about 0.2 . This means that the directors of a company that generates double the revenue of another one will have a $20 \%$ higher compensation, all other factors being equal. As for the financial structure of the company, it seems to have a small but significant effect on compensation. Thus, the companies with higher debt ratios pay a little bit more to their directors-it must be borne in mind that access to credit markets can be a sign of a company's progress. On the other hand, a greater ROE negatively affects compensation, which could imply a conflict of interest between shareholders and directors, although in practical terms, as we have shown, this variable has very small impact on directors' compensation. Another significant determinant that has been identified for companies is the sector in which they operate, where the real estate, oil refining and food product sectors are highly paid, while, on the other hand, transport, retail trade, metallurgy and accommodation sectors obtain below-average remunerations. One would expect that the highest paid sectors are also those where the knowledge, network and influence of directors have greater impact on the results.

Concerning the influence of the personal attributes of the directors, the position they hold on the board is particularly relevant, with executives (CEOs and Chairmen) enjoying a significantly higher remuneration. The fact that the gender variable is not significant is particularly relevant, so the apparent imbalance in average earnings is not mainly due to gender, but to other explanatory variables.

As for the random portion of the model, we find that a considerable proportion of the variation in director compensation is explained by the unobservable heterogeneity. Level 2 and 3 residuals may be related to unobserved variables that are relatively stable over time (in the short run), such as the talent, skills and political experience of the director, at level 2 (directors), or the degree of internationalization, corporate governance and R\&D expenditure of the company, at level 3 (firms). However, the level 1 residuals are linked to more isolated or uncommon events. In our opinion, the existence of malpractices by some individuals could be explanatory of level 2 and level 1 perturbations; however, as previously mentioned, we do not think that unfair practices have been common in the period following the financial crisis. The unequivocal existence of unobserved heterogeneity at two levels validates the hedonic theory of remuneration once we break the model assumption of equal efficiency; this is, if we admit that different individuals (directors) can present different levels of efficiency while performing the same job position.

The results of this research can offer guidance to those in charge of formulating both corporate policy (or company policy) and economic policy. In terms of corporate policy, the knowledge of the determinants of the director compensation can help companies set their directors' compensation, avoiding both overpaying their directors (with the consequent impact on their bottom line) and remunerating them below a "fair" remuneration; in this latter case, the company could experience a loss of talent (which could be difficult to replace) if its directors are tempted by more advantageous conditions from other companies. 
Our results may also be of interest from the point of view of economic policy. Currently, some political groups are asking Central Banks to create codes of conduct that limit executive compensation, particularly in those companies in which the State participates, or that are receiving public aid of some kind (subsidies, redundancy plans, etc.), or that are paying little to their shareholders. In these situations, the terms "too much" or "too little" compensation can be relative, so that the existence of a methodology for evaluating remuneration objectives can be useful when drawing up these codes of conduct - such as the one recently published by the Swiss Financial Market Supervisory Authority. On the other hand, our mixed model measures the temporary evolution of the expected compensation of the director (ceteris paribus); appealing to transparency, this data might be used by the regulator (and the society) to compare the growth of the director compensation with that of the rest of the workers.

Lastly, this study might also be of interest for young executives who aspire to cover board positions in the medium term, so that they can guide their training and experience toward those aspects that may have the greatest impact on their potential compensation.

Additional research would be welcome in this important field of study, for instance explaining what underlies the unobserved heterogeneity revealed by our analysis or identifying the random effects that change over time. In addition, we think that the multilevel approach deployed in this work has potential applications in the areas of finance, economics and accounting, given that disentangling both manager and firm effects is relevant and meaningful.

Acknowledgements We are grateful to the PAIDI research groups SEJ-513 and TEP-196, both of the Andalusian Government. Arcos-Vargas acknowledges the financial support received from the CERVERA research program of CDTI, the Industrial and Technological Development Center of Spain, under the research project HySGrid+ (CER-20191019). Usabiaga acknowledges the research project ECO201786780-R (Spanish Ministry of Economics, Industry and Competitiveness), for the funding provided. We acknowledge the comments and suggestions received from the Editors and Reviewers of Empirical Economics and the participants in the following conferences: 35th National Conference of Labor Economics (Italian Association of Labor Economists, 2020), XXII Encuentro Internacional de Profesores de Política de la Empresa (SanTelmo Business School, Seville, 2020), INFER 2020 Annual Conference and XXIII Encuentro de Economía Aplicada (2021). This paper has also been discussed with colleagues of the University of Seville and Pablo de Olavide University (Seville). All the remaining errors are our sole responsibility.

Funding Open Access funding provided thanks to the CRUE-CSIC agreement with Springer Nature.

\section{Declarations}

Conflict of interest The authors declare that they have no known competing financial interests or personal relationships that could have appeared to influence the work reported in this paper.

Open Access This article is licensed under a Creative Commons Attribution 4.0 International License, which permits use, sharing, adaptation, distribution and reproduction in any medium or format, as long as you give appropriate credit to the original author(s) and the source, provide a link to the Creative Commons licence, and indicate if changes were made. The images or other third party material in this article are included in the article's Creative Commons licence, unless indicated otherwise in a credit line to the material. If material is not included in the article's Creative Commons licence and your intended use is not permitted by statutory regulation or exceeds the permitted use, you will need to obtain permission 
directly from the copyright holder. To view a copy of this licence, visit http://creativecommons.org/licenses/ by $/ 4.0 /$.

\section{References}

Abowd JM, Kaplan DS (1999) Executive compensation: six questions that need answering. J Econ Perspect 13(4):145-168

Acero I, Alcalde N (2020) Directors' compensation. what really matters? J Bus Econ Manag 21(1):180-199 Aduda J (2011) The relationship between executive compensation and firm performance in the Kenyan banking sector. J Acc Taxation 3(6):130-139

Aggarwal RK (2008) Executive compensation and incentives. In: Eckbo BE (ed) Handbook of corporate finance: empirical corporate finance. Elsevier, Amsterdam, pp 497-538

Bebchuk LA, and Grinstein Y (2005) Firm expansion and CEO pay. NBER, Working Paper No. 11886

Bebchuk LA, Fried JM (2003) Executive compensation as an agency problem. J Econ Perspect 17(3):71-92

Bebchuk LA, Fried JM (2004) Pay without performance: the unfulfilled promise of executive compensation. Harvard University Press, Cambridge (Mass.)

Bebchuk LA, Fried JM (2005) Pay without performance: overview of the issues. J Corp Law 30(4):647-673

Bell B, and Van Reenen J (2016) CEO pay and the rise of relative performance contracts: a question of governance? NBER, Working Paper No. 22407

Bertrand M (2009) CEOs. Annu Rev Econ 1(1):121-150

Bertrand M, Mullainathan S (2001) Are CEOs rewarded for luck? The ones without principals are. Q J Econ 116(3):901-932

Bloom N, Van Reenen J (2007) Measuring and explaining management practices across firms and countries. Q J Econ 122(4):1351-1408

Brick IE, Palmon O, Wald JK (2006) CEO compensation, director compensation, and firm performance: evidence of cronyism? J Corp Finan 12(3):403-423

Bugeja M, Fohn S, Matolcsy Z (2016) Determinants of the levels and changes in non-executive director compensation. Acc Finance 56(3):627-667

Cahuc P, Carcillo S, Zylberberg A (2014) Labor economics, 2nd edn. MIT Press, Cambridge (Mass.)

Cameron AC, Trivedi PK (2005) Microeconometrics: methods and applications. Cambridge University Press, Cambridge

Chen Z, Keefe M (2018) Board of director compensation in China: to pay or not to pay? How much to pay? Emerg Mark Rev 37:66-82

Chen L (2017) Compensation, moral hazard, and talent misallocation in the market for CEOs. SSRN, Paper No. 2670083

Chiappori P, McCann RJ, Nesheim LP (2010) Hedonic price equilibria, stable matching, and optimal transport: equivalence, topology, and uniqueness. Econ Theor 42(2):317-354

Cordeiro JJ, Veliyath R (2003) Beyond pay for performance: a panel study of the determinants of ceo compensation. Am Bus Rev 21(1):56-66

Cordeiro JJ, Veliyath R, Eramus E (2000) An empirical investigation of the determinants of outside director compensation. Corp Gov Int Rev 8(3):627-667

Core JE, Holthausen RW, Larcker DF (1999) Corporate governance, chief executive officer compensation, and firm performance. J Financ Econ 51(3):371-406

Core JE, Guay WR, Larcker DF (2003) Executive equity compensation and incentives: a survey federal reserve bank of New York. Econ Policy Rev 9(1):27-50

Cremers KJM, Grinstein Y (2014) Does the market for CEO talent explain controversial CEO pay practices? Rev Finance 18(3):921-960

Djankov S, La Porta R, Lopez-de-Silanes F, Shleifer A (2008) The law and economics of self-dealing. J Financ Econ 88(3):430-465

Edmans A, Gabaix X (2009) Is CEO pay really inefficient? A survey of new optimal contracting theories. Eur Financ Manag 15(3):486-496

Edmans A, Gabaix X (2016) Executive compensation: a modern primer. J Econ Lit 54(4):1232-1287

Edmans A, Gabaix X, Jenter D (2017) Executive compensation: a survey of theory and evidence. In: Hermalin BE, Weisbach MS (eds) Handbook of the economics of corporate governance. Elsevier, Amsterdam, pp 383-539 
Eisfeldt AL, Kuhnen CM (2013) CEO turnover in a competitive assignment framework. J Financ Econ 109(2):351-372

Elson CM, Ferrere CK (2013) Executive superstars, peer groups and overcompensation: cause, effect and solution. J Corp Law 38(3):487-531

Essen MV, Heugens P, Otten J, Oosterhout JV (2012) An Institution-based view of executive compensation: a multilevel meta-analytic test. J Int Bus Stud 43(4):396-423

European Commission (2018) The european qualifications framework: supporting learning, work and crossborder mobility. Publications Office of the European Union, Luxembourg

Falato A, Li D, Milbourn T (2015) Which skills matter in the market for CEOs? evidence from pay for CEO credentials. Manage Sci 61(12):2845-2869

Farrell KA, Friesen GC, Hersch PL (2008) How do firms adjust director compensation. J Corp Finan 14(2):153-162

Fedaseyeu V, Linck JS, Wagner HF (2018) Do qualifications matter? New evidence on board functions and director compensation. J Corp Finan 48:816-839

Frydman C (2019) Rising through the ranks: the evolution of the market for corporate executives, 1936-2003. Manage Sci 65(11):4951-4979

Frydman C, Jenter D (2010) CEO compensation. Annu Rev Financ Econ 2(1):75-102

Frydman C, Saks RE (2010) Executive compensation: a new view from a long-term perspective, 1936-2005. Rev Financ Stud 23(5):2099-2138

Gabaix X, Landier A (2008) Why has CEO pay increased so much? Q J Econ 123(1):49-100

Gabaix X, Landier A, Sauvagnat J (2014) CEO pay and firm size: an update after the crisis. Econ J 124(574):F40-F59

García Martín CJ, Herrero B (2019) Women on the board: an analysis of Spanish listed firms. El Trimestre Económico 86(342):235-264

Goldstein H (2011) Multilevel statistical models, wiley series in probability and statistics. Wiley, Hoboken (NJ)

Graham JR, Li S, Qiu J (2012) Managerial attributes and executive compensation. Rev Financ Stud 25(1):144-186

Hahn PD, Lasfer M (2011) The compensation of non-executive directors: rationale, form, and findings. J Manage Gov 15:589-601

Hall BJ, Liebman JB (1998) Are CEOs really paid like bureaucrats? Q J Econ 113(3):653-691

Hamilton LC (2012) Statistics with stata: version 12. Cengage Learning

Hempel P, Fay C (1994) Outside director compensation and firm performance. Hum Resour Manage 33(1):111-133

Himmelberg CP, and Hubbard RG (2000) Incentive pay and the market for CEOs: an analysis of pay-forperformance sensitivity. SSRN, Paper No. 236089

Jensen MC, Murphy KJ, and Wruck E (2004) Remuneration: where we've been, how we got to here, what are the problems, and how to fix them. ECGI Working Paper Series in Finance, Paper No. 44-2004

Jensen MC, Murphy KJ (1990) Performance pay and top-management incentives. J Polit Econ 98(2):225-264

Johnston J (2002) Tenure, promotion and executive remuneration. Appl Econ 34(8):993-997

Jung HW, Subramanian A (2017) CEO talent, CEO compensation, and product market competition. J Financ Econ 125(1):48-71

Liu L, and Guo L (2017) Generalists versus specialists: the board's revealed perception of CEO general skill and CEO pay. SSRN, Paper No. 3020504

Ma M, and Pan J (2017) Firm-manager match and executive compensation. SSRN, Paper No. 3067808

Manzaneque M, Merino E, Banegas R (2011) Corporate governance issues and director compensation structure in spanish companies. Afr J Bus Manage 5(2):9164-9179

Matveyev E (2016) The labor market for corporate directors. SSRN, Paper No. 2667968

Matveyev E (2017) Sorting in the U.S. corporate executive labor market. SSRN, Paper No. 2482732

Meeks G, Whittington G (1975) Director's pay, growth and profitability. J Ind Econ 24(1):1-14

Melón A, Ruiz FJ, and Ruiz-Olalla MC (2020) The gender pay gap in the board of directors. An analysis with homogeneous groups of directors and compensation. AECA (Asociación Española de Contabilidad y Administración de Empresas), Mimeo

Murphy KJ (2013) Executive compensation: where we are, and how we got there. In: Constantinides GM, Harris M, Stulz RM (eds) Handbook of the economics of finance, vol 2. Elsevier, Amsterdam, pp 211-356 
Murphy KJ and Zabojnik J (2006) Managerial capital and the market for CEOs. Economics Department, Queen's University, Working Paper No. 1110

Murphy KJ (1999) Executive compensation. Marshall School of Business, University of Southern California, Mimeo

Nicholson GJ, Newton CJ (2010) The role of the board of directors: perceptions of managerial elites. J Manag Organ 16(2):201-218

Pan Y (2017) The determinants and impact of executive-firm matches. Manage Sci 63(1):185-200

Pinheiro JC, Bates DM (2000) Mixed-effects models in S and S-PLUS. Springer, New York

Rabe-Hesketh S, and Skrondal A (2012) Multilevel and longitudinal modeling using stata, Volume I: Continuous responses. Third edition, Stata Press, College Station, Texas

Rosen S (1974) Hedonic prices and implicit markets: product differentiation in pure competition. J Polit Econ 82(1):34-55

Rosen S (1981) The economics of superstars. Am Econ Rev 71(5):845-858

Rosen S (1982) Authority, control, and the distribution of earnings. Bell J Econ 13(2):311-323

Rosen S (1992) Contracts and the market for executives. In: Werin L, Wijkander H (eds) Contract economics. Blackwell, Cambridge, pp 181-211

Roth AE (2015) Who gets what and why: the new economics of matchmaking and market design. Houghton Mifflin Harcourt, New York

Ryan HE, Wiggins RA (2004) Who is in whose pocket? Director compensation, board independence, and barriers to effective monitoring. J Financ Econ 73(3):497-524

Sonenshine R, Larson N, Cauvel M (2016) Determinants of CEO compensation before and after the financial crisis. Mod Econ 7(12):1455-1477

StataCorp LP (2013) Stata multilevel mixed-effects. Reference Manual, Release 13, College Station, Texas Terviö M (2008) The difference that CEOs make: an assignment model approach. Am Econ Rev $8(3): 642-668$

Ting HI (2016) Why do board members receive excess compensation? Manag Decis Econ 37(8):552-562

Valero A, and Lucas JL (2011) Política de Empresa. El Gobierno de la Empresa de Negocios. EUNSA/ IESE, Pamplona

Publisher's Note Springer Nature remains neutral with regard to jurisdictional claims in published maps and institutional affiliations. 